\title{
La llengua en l'obra narrativa de Carmelina Sánchez-Cutillas: vers la construcció d'un model de referència al País Valencià
}

\section{Language in Carmelina Sánchez Cutillas' narrative work: towards the construction of a reference model in Valencian Country}

\author{
Josep Vicent Garcia Sebastià \\ josepv.garcia@gcloud.ua.es
}

\section{ISIC-IVITRA, Universitat d'Alacant}

\begin{abstract}
Resum: Aquest article descriu el model lingüístic en la prosa de Carmelina Sánchez-Cutillas per mitjà de l'anàlisi d'alguns usos fonortogràfics, morfosintàctics i lèxics extrets de Matèria de Bretanya i del relat curt «El llamp i la sageta de records». La conjuntura historicosocial en què l'autora publicà ambdós textos i l'èxit que ha tingut Matèria de Bretanya entre el públic lector valencià justifiquen la pertinència d'examinar les tries lingüístiques de l'escriptora. Tal com es prova de demostrar, Sánchez-Cutillas opta per fer servir un model que incorpora a la llengua comuna formes valencianes prestigiades pels usos cultes $\mathrm{i}$ algun dialectalisme de la comarca de la Marina Baixa, sense renunciar, però, a la màxima convergència amb la resta de parlars del domini lingüístic. En general, el model de l'escriptora coincideix amb el que propugnaven alguns dels gramàtics i dels lletraferits valencians de l'època, com ara Sanchis Guarner o Enric Valor.
\end{abstract}

Paraules clau: Carmelina Sánchez-Cutillas, narrativa, català contemporani, model de llengua, normativa

\begin{abstract}
This paper describes the linguistic model in Carmelina Sánchez-Cutillas' prose by means of the analysis of some morphosyntactic, lexical and phonetical spelling uses taken from Materia de Bretanya and from the short story «El llamp i la sageta de records». The historical-social context in which the author published both texts and the success achieved by Matèria de Bretanya among valencian readers justifies the relevance of examining the linguistic choices of the writer. As we aim at proving, Sánchez-Cutillas chooses to use a model that includes in standard language Valencian forms enjoying prestige due to their learned uses and some dialectisms form the region of the Marina Baixa, without giving up the maximum rapprochement with the rest of local ways of speaking within the linguistic domain. Generally speaking, the model of this writer coincides with that supported by some Valencian grammarians and literary figures of that time, such as Sanchis Guarner or Enric Valor.
\end{abstract}

Keywords: Carmelina Sánchez-Cutillas, prose, contemporary Catalan, language model, normative 
Josep Vicent Garcia Sebastià. La llengua en l'obra narrativa de Carmelina Sánchez-Cutillas: vers la construcció d'un model de referència al País Valencià

\section{La llengua narrativa de Carmelina Sánchez-Cutillas: matèria d'estudi ${ }^{1}$}

L'obra narrativa de Carmelina Sánchez-Cutillas té una rellevància destacable en el procés de construcció del català literari contemporani al País Valencià. Per bé que la producció en prosa de l'autora és escassa, hi ha almenys tres factors que justifiquen l'interès d'examinar-la amb una mirada lingüística. Són: les circumstàncies sociohistòriques en què es publicà Matèria de Bretanya, la qualitat expressiva de la seua proposta estètica i lingüística i, sobretot, la gran repercussió editorial i didàctica que tingué l'obra durant la Transició (Alpera 1997: 12; Borja 2010: 97; Esteve 2013: 157).

La guerra civil espanyola i la derrota del bàndol republicà estroncaren, d'una banda, el desplegament i la consolidació de les Normes de Castelló, així com la restauració del prestigi social del valencià, propugnat també per l'acord cívic del 1932 (Ferrando 2019: 286-333); d'altra banda, desarticularen el circuit literari, aleshores encara reduit, que s'havia anat gestant al sud del riu Sénia en el període anterior al conflicte (Carbó \& Simbor 1993).

Fet i fet, l'edició de la literatura catalana al País Valencià durant el tardofranquisme i l'inici de la Transició -període en què Carmelina Sánchez-Cutillas guanyà el premi Andròmina amb Matèria de Bretanya, l'any 1975- s'emmarcava en una conjuntura sociopolítica força hostil. En aquest sentit, Joan Borja ha qualificat la situació de la narrativa valenciana de postguerra de «quasi desèrtica» (Borja 2010: 97). Per la seua banda, Ferran Carbó i Vicent Simbor, que han definit el corpus novel lístic dels anys compresos entre el 1939 i el 1972, sostenen que en aquest període es publicà una quantitat d'obres significativament superior que en el primer terç del segle XX (Carbó \& Simbor 1993: 109111); però, alhora, assenyalen que les propostes estaven desfasades quant a l'estètica i les tècniques literàries, amb la qual cosa difícilment podien atraure -i, encara menys, consolidar- un públic lector potencial (Carbó \& Simbor 1993: 126-127).

El 1972 Fuster advertia que el País Valencià no tenia «una novel la pròpia» (Fuster 1972: 31). Llavors, es produí un canvi de tendència en la narrativa valenciana: sorgí una nova fornada de joves

\footnotetext{
*Aquest estudi ha estat desenvolupat al si de l'Institut Superior d'Investigació Cooperativa IVITRA [ISIC-IVITRA] de la Generalitat Valenciana (Programa de la Generalitat Valenciana per a la Constitució i Acreditació d'Instituts Superiors d'Investigació Cooperativa d'Excel lència [Ref. ISIC/012/042]), i en el marc dels projectes d'investigació següents: «Variació i canvi lingüístic en català. Una aproximació diacrònica segons la Lingüística de Corpus» (MICINUN, Ref. PGC2018-099399-B-100371); (IEC, Ref. PRO2018-S04-MARTINES); del Grup d'Investigación VIGROB-125 de la UA; la Xarxa d’investigació en innovació en docència universitària «Lingüística de Corpus i Mediterrània intercultural: investigació educativa per a l'aplicació de la Lingüística de Corpus en entorns multilingües diacrònics. Aplicacions del Metacorpus CIMTAC» (Institut de Cièncias de l'Educació de la UA, Ref. 4581-2018); i el Grupo d'Investigació en Tecnologia Educativa en Història de la Cultura, Diacronia lingüística i Traducció (Universitat d'Alacant, Ref. GITE09009-UA]).

1 Els professors Josep Martines Peres, Maribel Guardiola Savall i Vicent Beltran Calvo ens han ajudat a resoldre algun dubte en el procés d'elaboració del nostre estudi. Per això, mereixen un reconeixement en aquestes pàgines. Així mateix, agraïm les observacions i les propostes de millora que ens han fet els revisors anònims, les quals, sens dubte, han contribuit a millorar notablement la present publicació.
}

SCRIPTA, Revista internacional de literatura i cultura medieval i moderna, núm. 17 / juny 2021 / pp. 581 - 615 ISSN: 2340-4841 · doi:10.7203/SCRIPTA.17.20925 
escriptors que feu augmentar el volum de publicacions i que, alhora, començà a assajar un llenguatge literari renovador. És en aquest context en què cal situar l'aportació prosística de Sánchez-Cutillas a la literatura catalana. L'escriptor Josep Piera, en referència a la producció de l'escriptora, considera que

(...) la seua efímera presència literària va ser una lluminosa creació dels ambients renovadors de la literatura dels anys setanta, sorgida amb l'esclat estimulant que suposà l'aparició de l'editorial Tres i Quatre i els Premis Octubre (Piera 2009).

Adés avançàvem que Matèria de Bretanya havia tingut molt bona acollida entre els lectors valencians durant la Transició. Piera (2009) atribueix aquest èxit a dos factors: la capacitat creativa de SánchezCutillas i el valor afegit que li atorgà a l'obra el guardó del premi Andròmina.

\begin{abstract}
Van ser les qualitats literàries de l'autora, i la rellevància i la modernitat que aleshores tenia el premi Andròmina (...), les que feren de Matèria de Bretanya un llibre llegit i estimat per una generació que volia descobrir i refer un país amagat, i el feien i desfeien cantant cançons de Raimon, de Serrat, de Llach, de Sisa, o llegint La Plaça del Diamant, Et deix, amor, la mar com a penyora i Matèria de Bretanya, per exemple (Piera 2009).
\end{abstract}

I per a poder reconstruir els referents culturals, identitaris i lingüístics d'un país que havia estat postergat a la clandestinitat durant tant de temps, calia alfabetitzar la població en català. Hi havia, doncs, la necessitat de publicar lectures actuals que encaixaren amb aquest anhel de redescobriment. Matèria de Bretanya s'hi ajustava a la perfecció, car apostava pel «recurs a les arrels -l'evocació del món idíl lic i rural on havien viscut aquells infants que havien estat anys enrere els mateixos escriptors» (Salvador 2013: 160). Així explica Borja l'acollida editorial d'aquesta obra per part de la comunitat educativa entre les acaballes dels setanta i els inicis dels vuitanta:

Certament, aquest llibre de memòries ha estat un dels que més popularitat va adquirir entre els lectors valencians (...) en un moment tan important per a la història més recent de la literatura catalana com van ser els últims anys dels setanta $\mathrm{i}$ els primers dels vuitanta. $\mathrm{Al}$ fenomen, sens dubte, va col laborar decisivament la creació i la consolidació d'un mercat editorial associat a l'ensenyament de la llengua en els més diversos nivells, en un moment d'urgència alfabetitzadora davant la imminent recuperació del prestigi social de la llengua dels valencians que, després de l'obscuritat del règim franquista, es presentava finalment com una possibilitat real de la mà del procés democratitzador. La necessitat d'un corpus literari de suport per als cursos de llengua evidenciava la pràctica inexistència de textos que connectaren amb la realitat social dels valencians, que proporcionaren un model de llengua clar, entenedor i operatiu, i que serviren per a la fàcil i natural identificació dels lectors amb el seu temps i el seu país. Dit d'una altra manera: amb la simple expectativa de normalitzar seriosament l'idioma familiar dels valencians, descobríem l'absoluta anormalitat de la literatura produïda en els temps contemporanis, i l'absència - per exemple- de novel la valenciana constituïa un escandalós dèficit a l'hora de manipular textos literaris en les estratègies docents. Simplement per raons d'exclusió, doncs, Matèria de Bretanya va acabar sent un llibre de presència obligada entre les llistes que configuraven el circuit de lectures recomanades pels mestres que van estar pioners en la revolucionària generalització de l'ensenyament del valencià (Borja 2010: 97). 
Tot seguit, Borja afegeix: «La popularitat del llibre quedaria garantida si endemés resultava ser que l'obra s'oferia amb un model de llengua senzill, directe, col loquialitzant, d'aparença infantil (...)» (Borja 2010: 97). Efectivament, la utilització d'un llenguatge que simula l'oralitat és, d'acord amb Esteve (2013: 160), un dels trets més remarcables de Matèria de Bretanya. En un altre article analitzàvem les diferents estratègies lingüístiques de què se serví Sánchez-Cutillas per a configurar l'estil oralitzant de l'obra, el qual evoca la parla dels infants (Garcia 2017) -no debades, el caràcter conversacional i el to infantil de la veu narrativa són trets indissociables (Salvador 2013: 154). En aquell cas apuntàvem que la majoria de recursos que basteixen aquesta pretesa oralitat encara no s'havien descrit amb gaire detall.

Abans del nostre estudi, només se n'havia ocupat el professor Vicent Salvador (2013: 163-165), qui ja havia assenyalat les principals estratègies que atorguen a la narració una aparença col loquial: la preferència per una sintaxi eminentment paratàctica, la profusió de diminutius i d'onomatopeies, la literaturització d'algunes construccions de relatiu procedents dels registres informals, la tendència a la intensificació per mitjà d'elatius, redundàncies, etc., i la modalització del discurs efecte que s'aconsegueix amb la utilització de marcadors evidencials, com ara diu que o es veu que (Antolí 2015; Garcia 2017: 85-86), i amb l'ús de la segona persona del singular com a mecanisme d'impersonalització.

En aquesta ocasió destaquem que, en general, la llengua de Matèria de Bretanya -així com la d'altres textos de l'autora afins quant a l'estil- tampoc no ha rebut l'atenció que mereix. ${ }^{2}$ Fins ara, només l'han descrita amb un cert detall Beltran (2010) i Colomina (2010), els quals pronunciaren dues ponències sobre el tema -«El parlar d'Altea i el registre literari de Carmelina Sánchez-Cutillas» i «El model de llengua literària en Carmelina Sánchez-Cutillas» respectivament- en el curs «Carmelina Sánchez-Cutillas: Matèria de memòria», que se celebrà a la localitat d'Altea l'any 2010. També hi ha referències escrites al respecte, espargides pels diferents treballs que s'han escrit sobre la producció literària de Sánchez-Cutillas. La majoria destaquen el caràcter col loquial i líric (Broch 1980: 88-89), familiar i corrent (Balaguer 1993: 21), «riquíssim» (Casasses 2009) o simple i genuí (Pons 2017: 92) de les tries lingüístiques de l'escriptora. Segurament, una de les observacions més sagaces sobre la llengua literària de l'escriptora és la que fa Borja quan explica que la prosa de Matèria de Bretanya es troba

(...) a mitjan camí entre l'asèpsia de la llengua normativa -la neutralitat de les gramàtiques i els diccionaris-, l'estàndard literari que estaven utilitzant els escriptors de Catalunya, i la viva riquesa expressiva del parlar dialectal de la Marina Baixa (Borja 2010: 102).

El present article pretén, doncs, complementar l'afirmació de Borja per mitjà de l'enumeració i l'explicació d'exemples lingüístics concrets. Per dur a terme aquesta anàlisi hem examinat, a banda de Matèria de Bretanya (Sánchez-Cutillas 2015), «El llamp i la sageta de records», un relat breu que l'autora publicà l'any 1979 en L'Espill (Sánchez-Cutillas 1979) i que presenta afinitats

2 Casanova ha remarcat que, en general, «el component lingüístic es té poc present en els estudis de crítica literària» (Casanova 2009: 19). Sobre la llengua dels escriptors valencians contemporanis cf. Casanova i Garcia Frasquet (2009). 
esteticonarratives amb l'obra guanyadora del premi Andròmina del 1975. ${ }^{3}$ Hem prescindit de la narració «A la reverent e honrada Sor Francina de Bellpuig, monja professa al convent de la Puritat cara cosina nostra» (1981), en què Sánchez-Cutillas es fa passar per transcriptora d'un text medieval de sor Isabel de Villena; considerem que en aquest cas el model està condicionat per l'artifici de reproduir la llengua antiga.

L'estudi de les tries lingüístiques ens permetrà d'afinar la descripció del model de llengua en la producció narrativa més coneguda de l'autora. A més, també pot resultar pertinent per a comparar els usos de la prosa amb els de la poesia -gènere en què l'escriptora fou molt més prolífica-i per a contrastar les solucions que es priotitzen en Matèria de Bretanya i en "El llamp i la sageta de records" amb les que empraven els gramàtics i els lletraferits valencians coetanis.

D’acord amb els exemples que comentem en $\$ 2, \$ 3$ i $\$ 4$ (cf. infra), la llengua narrativa de Carmelina Sánchez-Cutillas es caracteritza per

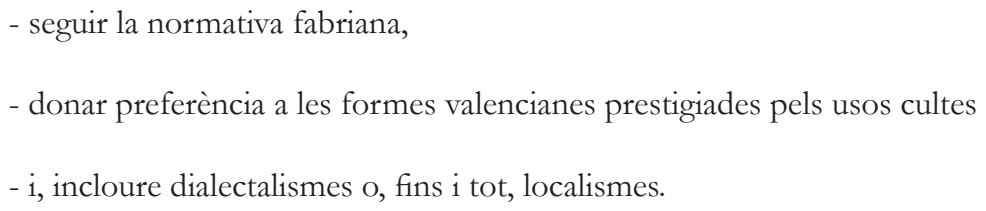

Amb tot, també s'alternen solucions geogràfiques diverses. Aquestes vacil lacions puntuals de vegades reflecteixen els dubtes lingüístics de l'autora. En altres casos -sobretot de tipus lèxic-, la combinació de formes diferents sembla que es deu més aviat a la integració deliberada de les distintes variants territorials de què disposa la llengua comuna (cf. \4.1).

D’acord amb Carbó i Simbor (1993: 28-38), la inseguretat lingüística era un problema bastant generalitzat entre la majoria d'escriptors de la postguerra. Recordem que les Normes de Castelló, que assumiren amb algunes especificitats la proposta normativa de Fabra, s'aprovaren tot just quatre anys abans que esclatés la guerra civil. Per tant, no es van poder revisar ni desplegar tal com hom hauria esperat en altres circumstàncies ni tampoc van aconseguir de «posar fi radicalment a les incongruències ortogràfiques i gramaticals de les publicacions dels escriptors valencians» (Ferrando 2019: 291). Les tries lingüístiques de Sánchez-Cutillas, doncs, també degueren estar condicionades per aquesta problemàtica. A més, cal tenir en compte que l'autora parlava el castellà com a llengua primera i el valencià l'aprengué més tard, una circumstància que explica la veu narrativa de Matèria de Bretanya:

(...) vaig començar a cridar des de la porta, «Mamà, Carlitos ha tirado un cerdo al agua». I gràcies que Maria Ronda mig plorant de tant de riure va explicar el lapsus linguae (...).

\footnotetext{
3 La veu narrativa de Matèria de Bretanya i de «El llamp i la sageta de records» és la mateixa, així com l'estil. La diferència entre totes dues obres rau en el període cronològic que s'hi narra: els anys anteriors a la guerra civil espanyola en la primera i el temps de la guerra en la segona.
} 
$\mathrm{Al}$ meu avi no li va fer gens de gràcia, i deia que era una vergonya que els seus néts no sabien parlar valencià. (Sánchez-Cutillas 2015)

La inseguretat lingüística dels literats de l'època cal emmarcar-la en la polèmica sobre quina llengua literària calia utilitzar al País Valencià. Les dues postures a l'entorn d'aquest debat es concretaven, d'una banda, en una concepció unitarista de la llengua i, d'altra banda, en una visió més policèntrica i convergent amb la resta de varietats del català. El primer posicionament, que optava per emprar les solucions convencionalitzades al Principat en la resta de territoris del domini lingüístic, va estar representat al País Valencià per Joan Fuster. El segon, en canvi, el van impulsar gramàtics com Sanchis Guarner i va ser assimilat per la majoria d'escriptors l'època. Aquests darrers eren «partidaris d'una major obertura a nivell literari per a diverses solucions, sobretot lèxiques, i en menor grau morfològiques, aportades pels diversos parlars catalans al parlar central barceloní, que havia servit de model bàsic per a l'elaboració de la llengua literària» (Carbó \& Simbor 1993: 30). Com veurem, Carmelina Sánchez-Cutillas s'adherí a aquest segon grup d'intel lectuals.

\section{E1 model fonortogràfic}

Els mecanoscrits de Matèria de Bretanya i de «El llamp i la sageta de records» dipositats a la caixa núm. 20 del llegat de Carmelina Sánchez-Cutillas a la Biblioteca Valenciana Nicolau Primitiu deixen entreveure que l'autora preferia l'accentuació tancada de la $e$ tònica, ${ }^{4}$ si bé és cert que hi ha una certa vacil lació formal. De fet, aquesta alternança de variants es mantingué en l'edició de «El llamp i la sageta de records» que es publicà a L'Espill (Sánchez-Cutillas 1979). Ho observem en els casos 1), 2) i 3), en què s’utilitza l'accentuació greu, i en 4) i 5), exemples d'ús de la forma aguda. ${ }^{5}$

1) (...) anàrem a missa a casa del marqués (...). LLSR $197^{6}$

2) El Coixo, com a president del Comité de l'Olla (...). LLSR 200

3) El tio Patilla no entenia el francés (...). LLSR 202

\footnotetext{
4 Aquesta variant ortogràfica, que es correspon amb la pronúncia dels parlars occidentals, començà a difondre’s a partir de les Normes de Castelló (Institut d'Estudis Catalans 2017: 94) i fou assumida pels principals gramàtics valencians del segle XX, com ara Sanchis Guarner (Ferrando 2019: 297).

5 En l'obra poètica predomina l'accentuació aguda de la $e$ tònica, però també hi ha casos en què s'utilitza la solució greu. En aquests versos, per exemple, s’opta per l’accent tancat: «jOh, com desitge estrényer coses palpables!» (SánchezCutillas 1997: 67); «Del pou del silenci/tréiem/petites converses» (Sánchez-Cutillas 1997: 91); «De vegades, però, hi ha un petit alé/amb desitjos de vida eterna» (Sánchez-Cutillas 1997: 138). En canvi, en aquest altre, del poema 15 de Els jeroglífics $i$ la pedra de Rosseta, es fa ús de l'alternativa oberta: «Si pogués estrènyer tota la història de l'home!» (SánchezCutillas 1997: 174).

6 En les abreviatures dels exemples les lletres indiquen l'obra (Matèria de Bretanya = MB; «El llamp i la sageta de records» $=$ LLSR) i els números, la pàgina.
}

SCRIPTA, Revista internacional de literatura i cultura medieval i moderna, núm. 17 / juny 2021 / pp. 581 - 615 ISSN: 2340-4841 $\cdot$ doi:10.7203/SCRIPTA.17.20925 
Josep Vicent Garcia Sebastià. La llengua en l'obra narrativa de Carmelina Sánchez-Cutillas: vers la construcció d'un model de referència al País Valencià

4) La dacsa, el sègol, l'ordi, el mestall i fins i tot el segó. LLSR 204

5) De les corfes de les faves no recorde quina cosa fèiem. LLSR 204

Per contra, en les edicions de Matèria de Bretanya (Sánchez-Cutillas 2015 [1a ed. 1976]) s'acaba prioritzant l'accentuació greu (è), la solució pròpia del català literari i per la qual també optaren altres escriptors valencians coetanis, com ara Enric Valor (cf., per exemple, l'ús que en fa aquest autor en el Cicle de Cassana):

6) (...) t'estalviaves el carrer de la Mar la costera de la Sèquia. MB 33

7) (...) i ens lligàvem a les espardenyes uns llistonets i fèiem cloc cloc (...). MB 39

8) (...) entre les tassetes de cafe i les copetes de licor dolcet (...). MB 50

9) (...) mare m'han tirat el cèrcol a la bassa! MB 51

10) (...) jo em sentia com si estigués tacada, tacada d'un pecat que no havia comès. MB 54

11) (...) malgrat que no fos marquès de debò, la gent li deia el marquès de dalt (...). MB 56

En aquest cas, l'accent obert de la $e$ tònica s'aplica a tots els casos de manera sistemàtica, la qual cosa suposa un canvi respecte al manuscrit que citàvem adés, canvi que podria haver estat motivat per una decisió editorial. ${ }^{7}$

La representació gràfica del vocalisme àton també presenta alguna vacil lació. Així, algunes formes característiques dels parlars orientals, com per exemple arrencar, treure -i el derivat distreure- o rodó, s'utilitzen al costat de variants etimològiques que reflecteixen la pronunciació del dialecte occidental, com és el cas de jaure:

12) (...) fer arrencar la màquina lligada als vagons (...). MB 44

13) (...) arrencà a plorar (...) MB 71

14) (...) la lluïssor dels ulls que no te la pots treure. MB 45

15) (...) Betriueta tren el berenar als xiquets. MB 57

16)I jo em preguntava si seria per la pluja o per distreure la gent. MB 91

17) (...) era una estora rodona feta d'espart. MB 57

18) (...) m'acabe de trobar al fons d'un calaix un fermallet rodó (...). MB 112

\footnotetext{
7 De tots els mots destacats en els exemples 6) i 11) -ambdós inclosos-, només cèrcol-9)- duu l'accent obert en el mecanoscrit de la Biblioteca Valenciana Nicolau Primitiu; la resta estan accentuats amb la forma tancada.
}

SCRIPTA, Revista internacional de literatura i cultura medieval i moderna, núm. 17 / juny 2021 / pp. 581 - 615 
Josep Vicent Garcia Sebastià. La llengua en l'obra narrativa de Carmelina Sánchez-Cutillas: vers la construcció d'un model de referència al País Valencià

En algun cas, es combinen ambdues solucions en un mateix paradigma verbal. Ho observem en nàixer/néixer o xarrar/xerrar.

19) (...) quan naixia un nen la comare posava una branqueta de ruda en la finestra de la cambra (...). MB 66

20) (...) no sé si la música i els versos neixen del fet guerrer (...). LLSR 201

21) (...) xarraven assegudes als cantons cercant la frescoreta (...). MB 56

22) No sé pas per què li deien mut, car xerrava molt encara que farfallejant. MB 86

En el consonantisme també testimoniem l'alternança del dígraf $t l / t l l$. De vegades, Sánchez-Cutillas opta per emprar la grafia $t l l$, que representa el so geminat palatal $[\lambda \lambda]$, característic de la majoria de parlars del Principat (PALDC: mapa 633): espatlla (MB 90), espatllar (MB 44), ametlla (MB 85), ametller (MB 35), vetllatori (MB 97). Però també utilitza l'alternativa gràfica $t l$, la qual es correspon amb la pronunciació alveolar [1] -i en algunes zones [1], sense geminació- pròpia del tortosí, el valencià, el, baleàric i l'alguerès (PALDC: mapa 633): espatla (MB 44), ametla (LLSR 200).

\section{Els usos morfosintàctics}

Per raons d'espai, no analitzarem detalladament tots i cadascun dels usos morfosintàctics que componen el discurs narratiu de l'escriptora. De fet, algun dels fenòmens que forma part d'aquest terreny, com ara la successió de construccions coordinades i juxtaposades o l'acumulació de diminutius que infantilitza la veu narrativa, entre altres, ja han estat descrits en els treballs que sobre l'oralitat o el to conversacional de Matèria de Bretanya (Salvador 2013: 163-165; Garcia 2017). No hi insistirem ara, sobretot perquè aquests casos que hem apuntat estan relacionats amb l'estil, i no tant amb la norma lingüística. Per tant, ens limitarem a presentar la resta de trets de l'àmbit de la morfosintaxi que considerem més significatius.

\subsection{Els possessius}

En els textos narratius que hem examinat atestem l'ús dels dos tipus principals de possessius de què disposa la llengua actual: els àtons i els tònics. Els primers els documentem sempre referits o bé a noms de parentiu que indiquen una relació ascendent ${ }^{8}$ o bé al substantiu casa:

23)Mon pare els proposà d'enviar la cuinera (...). LLSR 200

24) Però l'endemà ma mare va haver d'anar a allò de les ametles (...). LLSR 200

$8 \mathrm{El}$ substantiu avi també apareix introduit pel possessiu tònic corresponent: «El meu avi resava el rosari a sa casa (...)» (MB 40). D’altra banda, les relacions de parentiu que no suposen una relació ascendent mai no s'expressen per mitjà dels possessius àtons: «La baralla amb aquell salvatge (...) tingué un final inesperat quan el men germà (...) agafant d'un grapat el cèrcol el llançà al bassot (...)» (MB 51). 
Josep Vicent Garcia Sebastià. La llengua en l'obra narrativa de Carmelina Sánchez-Cutillas: vers la construcció d'un model de referència al País Valencià

25)He dit que mos pares no es barallaven per qüestions polítiques (...). MB 116

26) Quan les dones del fornet parlaven amb mon avi, se'ls encenia als ulls una llumeneta (...). MB 58

27) De tota la casa de mon tio Miquel, allò que més m’agradava eren les flors (...). MB 63

28) Ma tia Tereseta deia que aqueixes històries no eren més que desficacis (...). MB 128

29) Quan aplegava a ma casa ja era fosc (...). MB 39

Pel que fa als possessius tònics, l'autora empra de manera sistemàtica -també en la producció poètica (Sánchez-Cutillas 1997)- les variants femenines mena, teua i seua, les quals predominen en català occidental i septentrional; a més, són, «respectivament, les formes habituals en la llengua escrita culta de cadascuna d'aquestes àrees» (GIEC: 609):

30) (...) aquell arbre que creixia a la vora d'un marge (...) era la mena talaia. LLSR 200

31) (...) passaves el dit per dins i ja podies tirar la pilota que sempre tornava a la teua mà. LLSR 197

32) (...) i estava tota voltada de tossals apegats a les seues faldes com cadells mamant de la mare. MB 33

En Matèria de Bretanya també destaca l'ús del possessiu llur, una solució característica dels registres més formals de la llengua (GIEC: 614). A més, aquesta forma apareix sempre en posició postnominal:

33) (...) aquelles dones que exercien tothora el matriarcat llur sobre el poble. MB 79

34) (...) ens hauria agradat de fer-nos amics seus i d'aprendre els noms llurs. MB 110

Certament, es tracta d'un tret que contrasta amb les estratègies lingüístiques que atorguen al discurs narratiu una aparença col loquial (Salvador 2013: 163-165; Garcia 2017). De fet, el dualisme col loquialitat-formalitat és una constant en Matèria de Bretanya-i, en menor mesura, en «El llamp i la sageta de records». Valga com a exemple el cas 35), en què el possessiu llur fa referència a cossets, és a dir, a un substantiu tenyit d'afectivitat per l'ús del diminutiu:

35)Les casetes de les aranyes eren de seda brilladora, i elles filant filant molt atrafegades i sempre amunt $i$ avall amb el bri sedós que regalimava dels cossets llurs. MB 93

L'ús de les fórmules iteratives «filant filant» $\mathrm{i}$ «amunt $\mathrm{i}$ avall» com si fossen els verbs de les respectives proposicions coordinades realça el to col loquial del fragment. Aquesta estratègia simula la sintaxi pròpia de les narracions populars de base oral, i això fa ressaltar més encara la formalitat que hi aporta llur. 
Josep Vicent Garcia Sebastià. La llengua en l'obra narrativa de Carmelina Sánchez-Cutillas: vers la construcció d'un model de referència al País Valencià

\subsection{El gènere i el nombre d'alguns substantius}

El substantiu mar, que té una gran importància en l'imaginari literari de l'autora, apareix sempre usat com a femení:

36) La mar vivia en una badia molt gran. MB 33

37) Per la mar que teníem tan propet, la mar nostra i casolana (...). LLSR 198

Altrament, en Matèria de Bretanya, el gènere atorga al discurs un to culte, que remet a la llengua dels clàssics. És el cas de color, substantiu que s'utilitza com a femení en tots els casos, i flaire, que, per contra, es fa servir com a masculí en l'única ocurrència que documentem:

38) (...) i la boca (...) era de la mateixa color que les cireres del cirerer gran. MB 37

39) (...) es veu que se li pegava [sic] la color dels comiats (...) MB 44

40) (...) i ara tenia la cara de la mateixa color dels cigrons (...). MB 76

41) Sempre resàvem el rosari entre els flaires del bullit (...). MB 40

Del nombre, destaquem

a) l'ús dels plurals homes $\mathrm{i}$ marges, una mostra de la integració del model normatiu, en comptes de les alternatives menys generals hòmens $\mathrm{i}$ màrgens:

42) (...) els homes que tenien compte de la via ficaven de tant en tant mig tronc d'arbre travessat. MB 33

43)Homes que se n'anaven a fer la guerra amb espardenyes de careta (...). LLSR 198

44) (...) mitja dotzena de bancals i de marges $i$ en acabant la mar. MB 33

b) la preferència per la marca de plural -s en la terminació -sti en el dels mots acabats en -ig: ${ }^{10}$

45) Però aquests no arribaven mai (...). MB 128

46)I els assaigs els feia després de dinar (...). MB 120

En el cas concret del nombre, les tries lingüístiques de l'autora coincideixen parcialment amb la proposta que feu Sanchis Guarner per al valencià culte, ja que el gramàtic també optava pel model descrit en a), però, en canvi, prioritzava la marca -os en les terminacions consonàntiques exposades en b) (Ferrando 2019: 361).

\footnotetext{
9 En l'obra poètica també predomina la forma femenina: «El riu era la mar dels pobres (...)» (Sánchez-Cutillas 1997: 88). De fet, el substantiu mar només s'empra en masculí en un únic poema, i aquest ús està condicionat per la mètrica del decasíl lab: «(...) on res no importen els meus gallardets/ni els rumbs que haja fet pel mar de la vida» (Sánchez-Cutillas 1997: 134).

10 No hem trobat cap mot acabat en - sc o $-x t$ que estiga en plural.
} 
Josep Vicent Garcia Sebastià. La llengua en l'obra narrativa de Carmelina Sánchez-Cutillas: vers la construcció d'un model de referència al País Valencià

\subsection{Els quantificadors}

D’una banda, l'alternança de dos/dues davant mots femenins representa un altre exemple de vacil lació formal:

47)L'Aitana i el Puigcampana eren dues muntanyes punxegudes i migjornenques, que de tant mirar-se l'aigua se n'havien tornat blaves. (MB 33)

48) (...) jo em descordava les dos mançanetes de més amunt (...). (MB 42)

D’altra banda, destaca l'ús de quantificadors propis de la llengua formal, com ara gaire -49) i 50)_ o força-51). Notem, però, que gaire no segueix la pauta establerta pel català literari, atès que es fa servir en oracions afirmatives, un context en què no sol aparèixer:

49)Als nins ens agradava gaire dir casetes d'aranya, i la gent gran deia teranyines. (MB 93)

50) M'agradava gaire entrar al paster (...). (MB 96)

51) Però devia de ser força apassionant això de viure de dia com un mariner (...). (MB 47)

\subsection{Alguns usos preposicionals}

En general, les preposicions s'ajusten als usos cultes de la llengua. Ho observem, per exemple, en la distinció tradicional de peri per a davant d'infinitiu en construccions finals. Regularment, l'escriptora utilitza la forma simple si l'infinitiu depèn d'una oració principal constituïda per un verb d'acció voluntària:

52)(...) i només desitjàvem jugar vora la font per sentir la remor de l'aigua. MB 60

53) (...) per llevar-nos l'ensopiment del rés, [Cantarrana] ens explicava coses molt boniques. MB 72

54) (...) se n'anaven a Alacant per consultar les seues dolències al senyor Manolo (...). MB 74

55)L'alçaren per ficar-li el vestit dels dies de festa (...). MB 106

En canvi, prefereix la forma composta en els contextos següents:

a) Quan l'infinitiu no depèn d'un verb d'acció, sinó d'un verb que expressa necessitat, estat o obligació:

56) (...) ell romania allí mateix i aprofitava l'estona per a embolicar-se les cigarretes. MB 40

57) (...) els vells del poble que ja no servien per a anar a la mar o al bancal, s'asseien al sol (...). MB 84

58) (...) per a arribar al moro [= al nord d'Àfrica] s'havia d'aparellar una barca de sardinal (...). MB 81 
Josep Vicent Garcia Sebastià. La llengua en l'obra narrativa de Carmelina Sánchez-Cutillas: vers la construcció d'un model de referència al País Valencià

b) Quan l'infinitiu depèn de substantius o adjectius que no estan relacionats amb verbs d'acció:

59) (...) com les caixetes de soterrar els albats, que també tenien un vidre per a vore l'àngel (...). LLSR 199

60) (...) no hi havia res més bonic per a mirar (...). MB 38

Tanmateix, documentem alguna vacil lació puntual, com les dels exemples 61) i 62), en què els verbs deturar-se i venir, tots dos agentius, s'usen amb per $a$ :

61) (...) ma mare les pujava [les costeres] caminant a poc a poc i deturant-se per a alenar. MB 34

62) (...) les visites que venien per a comentar els fets de l'esdevenidor. MB 85

D'altra banda, i com a norma general, l'autora opta per fer servir la preposició de davant dels infinitius en funció de complement directe que poden o no anar precedits d'aquesta partícula $-\mathrm{O}$ que, directament, la requereixen-; fins i tot la utilitza en contextos poc habituals, com ara en una perífrasi d'obligació amb el verb caldre-65):

63) Aqueixa escaleta ens va costar prou feines de pujar. MB 70

64)A mi em feia empegueïment de demanar-li un didal (...). MB 81

65) (...) els calia de pagar amb petits treballs el plat de calent i el mos de saladura (...). MB 84

66) M'hauria agradat d'anar-me'n amb els altres xicons a caçar parotets (...). MB 106

Finalment, testimoniem l'ús preposicional de part, que, juntament amb una altra preposició o adverbi locatiu o de direcció indica una determinada posició en l'espai (DDLC, s. v. part, 16):

67)Els meus parents vivien part de dalt del poble (...). [= a la part de dalt del poble] MB 34

68) (...) sempre regalimava una goteta de mel o una goteta del suc de l'arrop part de fora del vidre.

69) [= per la part de fora del vidre] MB 114

En algun cas, l'autora usa aquesta estructura amb un sentit temporal:

70) I part de vespre, el forn de la costera on vivia Angeleta la Fustera s'omplia de llandes de fer col lació i de patir fam. [=al vespre] MB 60

71)I en aplegar la nit -part de dia, no- sempre en aplegar la nit, començava a envair-me la por. [= de dia, no] LLSR 203

El DCVB documenta construccions molt semblants en la llengua antiga; la diferència, però, és que (a) en aquests casos el mot part apareix precedit d'una altra preposició i, a més, (b) l'expressió assenyala la direcció o el moviment de l'acció verbal: «Lauar souent la boca del cauall de part de dins, Flos medic. 20» (DCVB, s. v. part). El diccionari també incorpora exemples d'escriptors del període contemporani, tots de Catalunya. Aquests casos s'assemblen més als que hi ha en la prosa 
Josep Vicent Garcia Sebastià. La llengua en l'obra narrativa de Carmelina Sánchez-Cutillas: vers la construcció d'un model de referència al País Valencià

de Sánchez-Cutillas: «Una altra pàtria ens espera part d'allà de les aigües [= a l'altra part de les aigües], Verdaguer Exc. 6» (DCVB, s. v. part). ${ }^{11} \mathrm{El}$ més probable, doncs, és que Sánchez-Cutillas adoptés aquestes construccions del model literari del Principat. Tanmateix, són estructures que encara estan per estudiar.

\subsection{Els pronoms febles}

La morfologia pronominal i la combinació de pronoms febles també s'adeqüen a les tries que els gramàtics com ara Sanchis Guarner o Enric Valor prioritzaven en aquella època per al català literari del País Valencià. Ho veiem en els fenòmens que enumerem tot seguit:

a) Ús de li com a forma de datiu singular i preferència per l'ordre datiu + acusatiu en les combinacions de tercera persona -li', li la, etc.- (Valor 1999a: 247-248; Ferrando 2019: 361) en lloc de les variants més antigues -l’hi, la hi, amb ordre invers i provinents de la dissimilació de $l$ (acusatiu) $+l i$ (datiu)-, les quals encara s'utilitzen com a formes generals en els parlars orientals i nord-occidentals, (GIEC: 211):

72) (...) li l'havia duta el seu marit de no sé quin país (...). MB 38-39

73) Encara no havia arribat a donar-lil (...). MB 40

74) (...) l'amo de la joguina no volia deixar-li-la. MB 51

75) (...) li's passava per la finestra gran que queia just al costat de la caseta. MB 90

b) Ús de les formes reforçades en posició preverbal sempre que el verb comence per consonant, propi del català literari contemporani:

76) (...) em pensava que havia de ser una cosa terrible. MB 41

77) (...) i si petjaves el sòl del saló vermell ningú no et sentia (...). MB 85

78)I es parlava de tot i es malparlava una mica de tots. MB 79

79) (...) en passar uns anys ens salvà la vida a tots sense saber que ens la salvava. MB 34

80) (...) jo en coneixia molts pocs, de republicans (...). MB 40

Amb tot, documentem un únic cas en què el pronom en manté la forma plena davant un verb començat per consonant. Val a dir, però, que s'utilitza en una seqüència de discurs reportat posada

11 En les citacions del DCVB, la cursiva dels exemples és nostra. 
en boca de la narradora, amb la qual cosa podria relacionar-se amb la intenció de l'autora de reproduir la parla oral: ${ }^{12}$

81) (...) vaig dir, no es preocupe, senyora Betacna, si ha de tastar pa i melva que mai no l'ha tastada, que tots els pobrets ne mengen MB 98

\subsection{Graus i formes de la dixi espacial}

Generalment, predomina el sistema ternari de dixi espacial, amb tres graus de locació. Aquest model, heretat parcialment de la llengua antiga, és el que s'ha acabat consolidant en valencià i en alguns parlars de la Franja (Pérez Saldanya \& Rigau 2011: 473). En el cas concret de la narrativa de Sánchez-Cutillas, els tres graus locatius es formalitzen per mitjà dels determinants i dels pronoms demostratius. Ho il lustrem amb casos concrets, disposats de major a menor grau de proximitat:

a) els determinants aquest, aqueix $\mathrm{i}$ aquell: ${ }^{13}$

82) (...) i un altre de color de cirera i aquest verd de fulla... MB 120

83)A mi em feia pensar en aqueixes casetes dibuixades sobre una cartolina (...). MB 37

84) (...) no he tornat mai més per aquell racó (...). LLSR 199

b) els pronoms açò, això i allò

85)I si dic açò és perquè més de quatre vegades els vaig veure entrecavant-li els bancals (...). MB 34

86)I això ens feia una miqueta de pena i per un moment restàvem en silenci (...). MB 45

87) Ma mare s’ho va creure i m’apallissà malgrat que jo jurava que allò era mentida (...). MB 53

c) Els adverbis demostratius, aci-forma característica de la majoria de parlars valencians i que també s'estén per algunes zones del català nord-occidental i del septentrional (ALDC: mapa 1979)_- ${ }^{14} \mathrm{i}$ allà:

88) Senyoreta: avui són d'ací dalt? MB 35

89)I el sol, indiferent a tots els esdeveniments del poble, seguia allà dalt (...). MB 62

12 Justament, sobre aquest mateix ús, Enric Valor sostenia el següent: «(...) se sent també usar la forma ne davant el verb. Per exemple: 'Ne tinc molts', 'Jo ne porte prou', etc. Es tracta d'un arcaisme, conservació d'una forma morfològica medieval enmig de la nostra llengua moderna. En la llengua literària no té cabuda actualment aqueixa forma» (Valor 1999b: 70). Per la seua banda, Beltran i Segura (2019: 207) afirmen que la forma plena del pronom en és viva en el valencià tortosí, en el septentrional, en el central i, excepcionalment, en el meridional.

13 En els textos narratius que ens ocupen, l'autora fa servir els demostratius reforçats de manera sistemàtica. Aquesta preferència està generalitzada en la producció literària contemporània d'arreu del domini lingüístic (Valor 1999b: 57)

14 En estadis anteriors de la llengua, l'adverbi ací tenia més extensió que no pas ara. Així ho explica el DCVB: «En el llenguatge modern, la forma ací té una forta tendència a desaparèixer cedint son lloc a aquí. A l'Empordà ja no diuen ací més que els vells; a Mallorca i Eivissa, és forma pròpia de la pagesia. En valencià conserva prou vitalitat» (DCVB, s. v. aci). 
No atestem l'ús del castellanisme abí, una interferència habitual en valencià col loquial. Per tant, quant a la dixi espacial, l'escriptora prioritza en la narrativa els sistemes $i$ les formes valencianes que més s'adeqüen als usos generals i formals de la llengua. De fet, les tries lingüístiques d'aquest àmbit de la gramàtica coincideixen exactament amb les que propugnava Sanchis Guarner (Ferrando 2019: 361).

\subsection{Flexió verbal i temps}

Les característiques principals de la flexió verbal són:

a) L'ús de la marca de 1a persona - $e$ en el present d'indicatiu dels verbs de la conjugació I, un tret definitori de la majoria de parlars valencians:

90) (...) açò sí que ho recorde molt bé. LLSR 197

91)I pense que és curiós com a vegades retornen a nosaltres els records (...). MB 51

b) La preferència per les formes amb eix dels verbs incoatius:

92) (...) quan la mar s'enterboleix i el mestral braveja (...). MB 115

c) La marcació del present de subjuntiu amb e, és a dir, amb les formes antigues que es conserven en valencià general, ${ }^{15} \mathrm{i}$ no amb la desinència $i$ :

93) (...) no tingues por que això són els gambosins. MB 83

d) La preferència pels imperfets de subjuntiu en -às, -és, -is -les variants clàssiques que Sanchis Guarner recomanava per a la llengua literària (Ferrando 2019: 361)-, ${ }^{16}$ en comptes de les formes en -ara, -era, -ira: ${ }^{17}$

94) (...) juga amb els nostres records com si jugàs amb aqueixes pilotetes que venien als porrats. LLSR 197

95)I nosaltres vivíem com si visquéssem a cavall entre el poble i Capnegret (...). MB 33

e) La preferència pels infinitius de la 3 a conjugació en -ir, com ara venir o tenir, una variant més general i amb més tradició literària que l'alternativa en -indre, tria aquesta que contrasta amb l'ús de la forma col loquial vore en «El llamp i la sageta de records» -98$):^{18}$

15 Segons la GIEC, les marques $e$ i $a$ del present de subjuntiu també es mantenen, tot i que en menor mesura, en «parlars nord-occidentals i residualment en alguns de baleàrics» (GIEC: 241).

16 Valor optà, en la praxi literària i en l'obra gramatical (Valor 1999a: 155-166), per un model molt semblant: -és (en lloc de -às per a la conjugació I), -és, -is.

17 En el mecanoscrit de Matèria de Bretanya que es conserva a la Biblioteca Valenciana Nicolau Primitiu l'autora substituí a mà les terminacions -ara, -era, -ira per les corresponents formes amb essa (cf. nota 18, infra).

$18 \mathrm{Amb}$ tot, documentem algun exemple de tindre en «El llamp i la sageta de records»: «(...) els meus germans i jo mai 
Josep Vicent Garcia Sebastià. La llengua en l'obra narrativa de Carmelina Sánchez-Cutillas: vers la construcció d'un model de referència al País Valencià

96) Diu que li va venir un rodament de cap (...). MB 106

97)I com que feia de majordom havia de tenir cura de la roba del seu senyor (...). $125 \mathrm{MB}$

98) Unes naus de guerra ocultes entre la foscor de la nit i el silenci de les màquines arades, però que algú va vore per la mar de Benidorm (...). LLSR 204

f) L'alternança, només en Matèria de Bretanya, de les formes va-/vare- en el passat perifràstic -si bé és cert que la primera és significativament més freqüent:

99) I van passar així una estona. MB 48

100) (...) els riu-raus varen perdre el seu ofici de guardar els canyissos del raïm (...). MB 123

Quant a la configuració del temps verbal, destaca l'ús esporàdic de la primera persona del singular del passat simple. En tots els casos documentats, aquesta solució s'utilitza en seqüències que alternen amb les formes perifràstiques. Els fragments següents ho il lustren a tall d'exemple:

101) El dimarts següent un home foraster va parar una parada de quincalla al mercat, i jo d'amagat li comprí el fermall amb el retrat dels dos afusellats. MB 113

102) Per això li digui a sa mare que si no el despullava que se l'hauria de despullar ella. Ma mare també li va dir que si no l'acurtava prompte (...) se li encendria de borradura. MB 119

Segons la GIEC, en la llengua escrita, les «variants perifràstiques alternen amb les variants simples del passat en totes les formes excepte en la primera, atès que la variant simple de la persona 1 és inusual» (GIEC: 251). Aquest tret tan poc habitual en la literatura el trobem en 102) i en altres fragments similars al llarg de les obres que ens ocupen i podria explicar-se per la influència del valencià central en el model de llengua de l'autora. No hem d'oblidar que Sánchez-Cutillas vivia a la ciutat de València -per bé que passava alguna temporada a Altea.

\section{E1 lèxic}

En l'àmbit del lèxic, el tret més rellevant del model lingüístic de Carmelina Sánchez-Cutillas és, sens dubte, la integració de vocables de procedència diversa: formes que remeten als textos clàssics, paraules vives en el català de la Marina, solucions del valencià general avalats pels usos formals -i altres d'extensió més reduïda-, mots difosos per la llengua literària contemporània i, també,

més no tornaríem a tindre joguets» (LLSR 205). De fet, en una de les correccions manuscrites del relat conservada en el llegat de Carmelina Sánchez-Cutillas a la Biblioteca Valenciana Nicolau Primitiu, l'autora es debat entre l'ús d'una variant o l'altra: «Vindre serà dialectal però m’agrada més»; i tot seguit afegeix: «el mateix em passa amb tinguerem [sic] i tinguessem [sic]». Aquests notes il lustren la inseguretat lingüística de l'escriptora, un fet que ja hem apuntat en $\mathbb{S}$. (cf. supra). 
variants característiques del català central, el dialecte sobre el qual es va fonamentar la codificació fabriana a començaments del segle XX.

\subsection{L'ús de geosinònims i altres tipus d’alternança lèxica}

La diversitat formal del nivell lèxic s'observa clarament en la variació sinonímica. D’una banda, l'autora forní la seua prosa d'un nombre considerable de geosinònims. Aquesta mateixa estratègia la feia servir Enric Valor en la seua producció literària. L'objectiu de Valor era prestigiar les variants més acostades al seu parlar per incorporar-les al lèxic comú i, alhora, donar a conèixer les solucions d'altres dialectes o de la llengua culta al lector valencià (Martines Llinares en premsa). D’altra banda, en la narrativa de Sánchez-Cutillas també integra sinònims de caràcter general -que no depenen de cap distribució dialectal concreta- (cf. matxo/mul) i, fins i tot, parells d'unitats lèxiques que presenten matisos semàntics entre si (cf. tio/oncle). Amb els testimonis següents exemplifiquem tots aquests tipus d'alternança:

algeps/guix

103) (...) en aquell país no feien les parets ni amb algeps ni amb pedres ni amb rajoles (...). MB 39

104) (...) I aqueixa mitja llum, com una boira ombrívola, allargava les figures de guix de la colla d'apòstols que voltaven tot el temple per dalt de les columnes (...). MB 55

Per bé que guix era un mot habitual en el valencià de l'edat mitjana (Martines Peres 2012: 164166), actualment només ocupa el català oriental, amb alguna incursió en el nord-occidental; així, la paraula que designa el 'sulfat de calci hidratat' al País Valencià contemporàniament és algeps (PALDC: mapa 1082). La variant guix es conserva al sud del riu Sénia amb el sentit de 'clarió', però aquest no és l'ús que en fa Sánchez-Cutillas. L'escriptora empra aquesta forma amb el significat específic de 'escaiola', tal com suggereix l'exemple 104).

dolent/roi

105) Sí, ja recorde un poc més, i m’hi veig amb la colla d'amics preguntant-nos si aquells morts que deia la cançó serien bons o serien roïns. Nosaltres sabíem que la gent dolenta escapça i mata, i que la gent bona ho perdona tot. (MB 112)

Ambdós adjectius apareixen sempre referits a persones i amb el sentit de immoral, que tendeix a fer el mal', un ús que en el cas de la forma roí sembla que només és propi del País Valencià (DCVB, s. v. roí, 2).$^{19}$ D'altra banda, cal assenyalar que 105) és un dels pocs exemples en què els dos sinònims del doblet apareixen en un mateix fragment. En la majoria dels casos, l'alternança de formes es troba dispersa per distintes parts de la narració. ${ }^{20}$

19 El fet que s’opte per roí i no per roín, una variant més usual, també és remarcable.

20 Aquesta característica distingeix l'obra de Carmelina Sánchez-Cutillas de la d'Enric Valor, en la qual l'estratègia

SCRIPTA, Revista internacional de literatura i cultura medieval i moderna, núm. 17 / juny 2021 / pp. 581 - 615 
Josep Vicent Garcia Sebastià. La llengua en l'obra narrativa de Carmelina Sánchez-Cutillas: vers la construcció d'un model de referència al País Valencià

eixir/sortir

106) De tant en tant els xicons eixiem a la via al pas del tren (...). (MB 45)

107) A l'endemà de la funció sortien els forasters del poble (...). (MB, 88)

Com és ben sabut, la forma que s'ha mantingut al País Valencià fins al període contemporani és eixir. El verb sortir, per contra, s'ha consolidat modernament en el bloc oriental i en gairebé tota la resta de parlars occidentals. No obstant això, aquesta variant també té una certa extensió en valencià septentrional i, en general, s'ha conservat en la resta de terres valencianes en determinats derivats i com un verb marcat que expressa valors intensius (Martines Peres 2012: 284-286). En l'obra de Carmelina Sánchez-Cutillas, però, els dos verbs s'empren com a sinònims, amb la qual cosa l'ús d'un o l'altre no implica cap tipus de matís semàntic. ${ }^{21}$

\section{clivell/escletxa}

108) Per tal que els xicons aprenguéssem a estalviar ens compraren unes vedrioles de terrissa blanca, com si foren canterelles però sense anses, i en comptes de tenir el foradet d'eixir l'aigua tenien una escletxa per on es ficaven els cèntims i les pessetes. MB 100-101

109) I jo els tancava un poquet sense tancar-los del tot, i per l'escletxa que fan els ulls pels costats quan no els has apretat prou, mirava per veure si tenia cos de carn o cos de pasta de nina (...). MB 77

110) (...) per les escletxes d'aquell silenci momentani penetrava tot seguit la veu de les campanes tocant a mort. MB 68

111)I la mà de la febre (...) s'apropiava dels nostres somnis sense deixar ni un clivell per on se'ns poguessen endinsar els pensaments amables. MB 110

L'exemple 111) representa l'únic cas en què documentem l'ús de clivell en la producció prosística que ens ocupa. El DDLC defineix el vocable com una variant de la forma femenina clivella; alhora, inclou clivella en una de les accepcions de la paraula escletxa: 'obertura allargada i poc profunda produïda en una superfície com la pell, la fusta, la roca o la paret en contraure's' (DDLC, s. v. escletxa, 2). Però el significat que adopta en 111) és figurat, igual que el d'escletxa en 110). Altrament, la interpretació que fem del mot escletxa en 108) i 109) es correspon amb sentit 'interval molt estret i allargat entremig de dos cossos, de dues superfícies, de dues parts d'una superfície pròxims' (DDLC, s. v. escletxa, 1b). Siga com siga, clivell és una solució del català oriental (DCVB, s. v. clivell), mentre que escletxa deu haver estat una paraula difosa contemporàniament per la llengua literària del Principat. En cap cas no documentem badall o clevill, alternatives més habituals al País Valencià.

d’explotar la variació sinonímica és molt més explícita i, fins i tot, didàctica (Martines Llinares en premsa).

21 Dels dos verbs, eixir és el més freqüent. De fet, sortir només l'hem documentat en un únic cas -el que exposem en l'exemple 107). 
Josep Vicent Garcia Sebastià. La llengua en l'obra narrativa de Carmelina Sánchez-Cutillas: vers la construcció d'un model de referència al País Valencià

espill/mirall

112) $\mathrm{Al}$ rebedor i a la sala de menjar hi havia quadres penjats, lluents com els cromos dels calendaris, $\mathrm{i}$ un paraigüer a l'entrada del carrer amb un espill al mig (...). MB 45

113) I quan jo era a soles em mirava a l'espill de la meua cambra (...). MB 103

114) Deia que la lluna era feta de trossets de miralls (...). MB 72

115) Quan les bassetes estaven a punt d'endurir-se eren transparents com els miralls (...). LLSR 199

La competència entre espill i mirall ja es documenta en català antic. Actualment, el primer vocable és el més usual en una gran part del català occidental, mentre que el segon es fa servir sobretot en català oriental i s'endinsa en alguna àrea del nord-occidental (PALDC: mapa 176). Amb tot, aquesta distribució no deu correspondre amb la de l'època medieval, atès que mirall també és present en textos valencians antics (DCVB, s. v. mirall, 2a). El que realment interessa remarcar és que Sánchez-Cutillas combina totes les dues solucions en la prosa, tal com demostren els exemples 112), 113) i 114) i 115).

esguitar/esquitxar

116) (...) sense saber com et topes amb el primer graó de l'escala de l'Església, tota enrajolada de lloses d'una pedra negrenca que té com uns esguitons blancs. MB 120

117) De tant en tant una gota d'aigua, en pegar contra una pedra més grossa, ens esguitava i després s'anava escolant per sobre la nostra carn com un petit rierol. MB 57

118) (...) i ficaven testos amb plantes de florir, per això [els riu-raus] sempre estaven com si estiguessen esquitxats de taquetes de colors (...). MB 123

A banda de esguitó -diminutiu d'esguit-, 116) i de esguitar, 117), que són mots d'una extensió considerable al País Valencià (Martines Peres 2000: 180), testimoniem també un exemple de esquitxar, 118), forma generalitzada en la resta de parlars del domini lingüístic (DCVB, s. v. esguitar) esquitxar), ${ }^{22}$ fins i tot en alguns punts del valencià septentrional (DECat, s. v. esquitxar).

\section{espatla/ muscle}

119) Però com que [la Fonda de l'Estrel] estava part d'enllà del carrer, per les espatles donava a la mar. MB 44

120) (...) nosaltres ens recolzàvem també, malgrat que teníem diners, sobre les espatlles i sobre la suor de l'home que treballava els nostres bancals. MB 90

121) (...) i el fusell enganxat d'una corretja i la corretja passada pel muscle esquerre. MB 47

22 El DCVB localitza la forma antiga esquitar a Xàtiva, a Mallorca i a Eivissa (DCVB, s. v. esquitar). El DECat (s. v. esquitxar) també la documenta a Castalla, a Sueca, a Onda i al Baix Maestrat.

SCRIPTA, Revista internacional de literatura i cultura medieval i moderna, núm. 17 / juny 2021 / pp. 581 - 615 
Josep Vicent Garcia Sebastià. La llengua en l'obra narrativa de Carmelina Sánchez-Cutillas: vers la construcció d'un model de referència al País Valencià

En valencià, el vocable més general per a designar 'la part superior i lateral del cos situada a cada costat del coll, en la unió del braç amb el tronc' és muscle. La variant espatla s'estén pels parlars orientals -amb la corresponent pronúncia palatalitzada- i s'endinsa en el nord-occidental (ALDC: mapa 81). Amb tot, aquest no és un mot desconegut al País Valencià. El DCVB el documenta en textos valencians medievals amb el sentit específic de 'part posterior del muscle': «Ferir en les espatlles o donar per les espatlles: (ant.) atacar per darrera, per reraguarda. L'altre uenga, e fira'l per les espalles, e derrocar-l'em en terra, Jaume I, Cròn. 60. Feriren en les spatles dels moros, Tirant, c. 331» $»^{23}$ (DCVB, s. v. espatla 2). Valor sosté que aquesta «és precisament la distinció que generalment fa el poble valencià, i la creiem molt útil per a la llengua literària» (Valor 1999b: 216). Aquesta distinció l'observem en l'ús que en fa Sánchez-Cutillas en l'exemple 119) -encara que l'autora també empra espatlla ${ }^{24}$ com a sinònim absolut de muscle, tal com es dedueix del contrast entre els casos 120) i 121).

\section{farigola/friula/ timó}

122) Per les mateixes olors jo li podia endevinar els passos, i era com si em regalàs, però sense saber que m'ho regalava, argelacs d'Aitana, heura i baladres del barranc del Garroferet, greda del tossal del Molar, camamilla i farigola i herba d'amanir olives dels vessants de Bèrnia. MB 94

123) (...) parlaven de les plantes i dels arbres que es criaven entre aquells penyals: heura i falzia, escabiosa i cards, friula i aurons, teixos i argelaga, albarzers i freixes, dauradelles i vesc. MB 127

124) (...) el timó i la sàlvia i la camamirla posats a remulla en aiguardent convertien aquesta beguda en una altra més bona que es deia herbero. MB $127^{25}$

Tal com observem en 122) i 124), l'escriptora utilitza les solucions més generals a tot el domini lingüístic per a denominar la planta aromàtica Thymus vulgaris: farigola i timó respectivament. D’acord amb les dades del PALDC (mapa 723), farigola s'estén pel català oriental peninsular, encara que també és una forma viva en altres territoris i sota formes diverses. Entre aquestes altres àrees hi ha una part de la Marina Alta i la Safor (DECat, s. v. farigola) - i també de la Marina Baixa (Colomina 1991: 207; Martines Peres 2012: 149). Així, el DCVB (s. v. friula), Colomina (1991: 207) i Beltran i Segura (2019: 290) localitzen friula a Altea, una variant que Sánchez-Cutillas també incorpora a la seua prosa -123). Per la seua banda, timó té una extensió general en els dialectes occidentals (PALDC: mapa 723). ${ }^{26}$

23 Respectem la cursiva del DCVB.

24 Sobre l'alternança del tipus espatla/ espatlla cf. \$2. (supra).

25 Els exemples 122), 123) i 124) també il lustren la variació formal en la designació d'altres dos fitònims: camamirla -122)-( camamilla-124)- i argelac-122)-(argelaga-123).

26 Per a una descripció detallada de la presència de farigola i les diverses variants d'aquesta denominació al País Valencià, cf. Martines Peres (2012: 148-150).

SCRIPTA, Revista internacional de literatura i cultura medieval i moderna, núm. 17 / juny 2021 / pp. 581 - 615 
Josep Vicent Garcia Sebastià. La llengua en l'obra narrativa de Carmelina Sánchez-Cutillas: vers la construcció d'un model de referència al País Valencià

joguet/joguina

125)Llavors, el meu germà més gran li'l va demanar [el cèrcol] i l'amo de la joguina no volia deixar-li-la. MB 51

126) (...) nosaltres pensàvem que els riu-raus tenien el nom joguinós i els fèiem servir per a jugar. MB 122

127) Tota una tragèdia soterrada entre els papers, els retalls, els joguets de la vida d'una xiqueta (...). MB 112

128) (...) els meus germans i jo mai més no tornaríem a tindre joguets. LLSR 205

La denominació joguet és d'ús habitual en valencià i en rossellonès, segons el DCVB (s. v. joguet). En la prosa de Sánchez-Cutillas alterna amb joguina-125)-, més freqüent en la resta del domini, i joguinós-126)-, un derivat d'aquesta variant.

\section{Llanda/ llauna}

129) (...) el forn de la costera on vivia Angeleta la Fustera s'omplia de llandes de fer col lació i de patir fam. MB 60

130) El meu avi resava el rosari a sa casa, a soles i sense donar la llanda a ningú. MB 40

131)I la fàbrica del carrer de la Mar (...), la feien servir de magatzem de les coses que enviava el Socorro Rojo Internacional: pots de llet i de carn, algun sac de llentilles, llaunes de confitura (...). LLSR 203

En aquest cas, la variació es produeix si contrastem Matèria de Bretanya amb «El llamp i la sageta de records». En el primer text l'autora opta per la forma valenciana llanda, 130): la utilitza amb el sentit de 'rostidora, recipient pla i de vores baixes que serveix per a coure menjars al forn ${ }^{27}$ i, a més, la integra en la locució donar la llanda ('molestar'), 131); en el segon, prioritza llauna, 124), d'abast més general.

matxo/mul

132) Per això el poble patia set d'aigua, $i$ anaven homes pels carrers venent-la, i la duien dalt d'un matxo amb tres cànters a un costat de la sària i tres més a l'altre costat. MB 91

133) (...) quan bufava el vent llevant, que trau l'alga de la mar, s'omplia la platja d'homes i de xicons que n'arreplegaven tota la que podien, i després la carregaven sobre els muls o els burros que havien dut a posta. MB 53

En català, mul és la forma clàssica i genuïna de designar el 'mascle híbrid de cavall i somera o d'ase i egua'. Amb tot, el sinònim matxo, castellanisme documentat ja en el segle XV (DCVB, s. v. matxo, 1), s'ha acabat imposant en la llengua moderna; per això, el PALDC (mapa 860) el localitza com a solució general arreu del domini lingüístic.

27 El DCVB (s. v. llanda, 3) també localitza aquest ús a Calaceit.

SCRIPTA, Revista internacional de literatura i cultura medieval i moderna, núm. 17 / juny 2021 / pp. 581 - 615 ISSN: 2340-4841 · doi:10.7203/SCRIPTA.17.20925 
Josep Vicent Garcia Sebastià. La llengua en l'obra narrativa de Carmelina Sánchez-Cutillas: vers la construcció d'un model de referència al País Valencià

prompte/aviat

134) Allí vivien les Comandantes: una mare i dues filles fadrines i velles. (...) per a elles [Isabelita] era la xicoteta, i pensaven encara que qualsevol dia en veure-la un senyor d'aquells que viatjaven en el tren el deixaria [sic] ben aviat i pujaria la costereta pedregosa per tal d'anar-hi a demanar-la (...). MB 37

135) Aquell problema tan terrible de voler donar i no trobar pas qui acceptàs el regal, el varen solucionar ben aviat. MB 115

136) Prompte s'ompliria el poble del soroll de les campanes tocant a mort (...). MB 106

D’acord amb Enric Valor, al País Valencià aviat «s'usa només en sentit adjectiu: Ja estàs aviat?, és a dir, "prompte, prest, dispost”》 (Valor 1999b: 94-95). Aquest ús es correspon amb el que observem en l'exemple 134). De tota manera, trobem casos en què aviat adopta una funció adverbial, com ara en 135), amb la qual cosa Sánchez-Cutillas també empra aquest mot com a sinònim de prompte, 135).

Justament, en el capítol de Millorem el llenguatge (1999) que Valor dedica als vocables prompte i aviat, l'escriptor i lexicògraf justifica la pertinència d'aprofitar la variació sinonímica i diatòpica en la creació literària. Aquesta és una estratègia que ell mateix aplicà en la seua producció narrativa tal com apuntàvem a l'inici del present apartat- i que, al nostre parer, també aprofità Carmelina Sánchez-Cutillas. Heus ací l'explicació que en fa l'autor castallut:

Tots sabem d'aquest ús [adverbial] del mot aviat, molt estés en el Principat de Catalunya. (...) Mot molt legítim (...), el trobem usat per literats valencians del nostre temps quan, per evitar la repetició de l'habitual prompte, ho consideren convenient per a la bellesa de l'estil. Per contra, prompte, que és avui dia d'ús típicament valencià, també ha estat utilitzat per escriptors de la Renaixença en el Principat: «Llum que s'apaga prompte», llegim en Jacint Verdaguer.

Amb açò, el nostre idioma no fa sinó com el francés, el castellà i altres llengües cultes, que empren els mots que són propis de l'idioma, sempre que siguen correctes, sense tenir en compte si s'usen més o menys en el llenguatge col loquial d'aquesta o de l'altra regió (Valor 1999b: 94-95).

\section{rent/llevat}

137) M'agradava gaire entrar al paster, sempre amb aqueixa foscoreta $i$ aquell silenci, però sobretot sempre amb la mateixa olor de rent, que a mi em semblava com una certitud de renovació i de cosa viva. MB 96

138)I les mones, que eren molt senyores, dormien el seu somni de llevat sobre la post de dur el pa al forn, ben embolicades dins un tovallol ratllat amb ratlles roges i grogues. MB 62

La denominació predominant en català de 'la massa fermentada que es mescla amb una altra per fer-la fermentar' és llevat, la qual coincideix, a més, amb la forma que s'utilitza a la Marina. Tal com exemplifiquem en els casos 137) i 138), en la narrativa de Sánchez-Cutillas aquest vocable alterna amb rent, un mot d'extensió més reduïda que s'estén per part pel valencià central i part del nordoccidental (PALD: mapa 696). 
Josep Vicent Garcia Sebastià. La llengua en l'obra narrativa de Carmelina Sánchez-Cutillas: vers la construcció d'un model de referència al País Valencià

roig/vermell

139) (...) un dia li vaig comprar una caixeta, la qual per dins era de setí roig $i$ tenia un espill (...). MB 81

140) (...)I els parotets també s'acostaven al xipoll perquè semblava que els agradava de mirar-s'hi, tan bonics, amb les ales blaves o vermelles. MB 58

141) (...) vull dir que al costat d'una flor groga venia un ramell verd, i una flor color de bacora, i un ramellet verd i una flor vermella, i una altra de vermella també, com si l'enrajolador s'hagués embolicat amb tanta floreta $\mathrm{i}$ tant de color. MB 63

142) I al saló vermell, que només l'obrien que els dies assenyalats, sempre hi havia foscor, perquè els cortinatges de domàs granat mai no deixaven entrar la claror (...). MB 85

143) (...) entraren a una botiga on venien sales de bany i va demanar a l'amo de la botiga un bidet, i la filla de la Comandanta com que mai no havia vist una cosa semblant li va preguntar a ma mare que per a què volia allò, i ma mare es va fer roja fins als cabells (...). MB 38

144) (...) jo feia com que em mocava o com que tossia per poder-me posar les mans davant les galtes i que no se n'adonassen, de la meua rojor (...). MB 41

145) (...) sobre la taula de trossejar el gel tenia una posteta i damunt de la posteta un grapat de pasta de sucre roig de fer aquells purets que tant ens agradaven als xiquets. MB 108

Per bé que roig és la forma més habitual al País Valencià a les hores d'ara, la denominació vermell devia ser més general per terres valencianes en altres estadis anteriors de la llengua. L'ALDC (mapa 1976) encara localitza l'adjectiu vermell en unes poques àrees del migjorn valencià -sovint com a segona resposta-, entre les quals hi ha la Marina Baixa. Contemporàniament encara perviu al sud amb valors específics, referit, per exemple, al fet de ruboritzar-se (Colomina 1991: 335-336). No obstant això, en la narrativa de l'escriptora vermell no adopta cap matís semàntic concret, sinó que més aviat funciona com a sinònim de roig; ho prova l'equivalència entre els usos de roig i vermell que es dedueix dels casos 139), 140), 141) i 142). De fet, roig és la forma que presenta més sentits. Així, a banda dels usos més prototípics, representats en 139), documentem exemples en què l'adjectiu integrat en la locució fer-se roig fins als cabells-i el substantiu rojor designen, justament, el rubor produït per una sensació de vergonya o de modèstia -143) i 144) respectivament; també trobem roig en la col locació sucre roig ('sucre sense refinar'), 145)

tio/ oncle

146) Aquell qui no volgués caminar, per un quinzet podia prendre la galera del tio Xinelo (...). MB 34

147) La coveta de la tia Pepa la Cuetera feia bafor d'humitat i de confitura tot barrejat (...). MB 108

148) I això de resar el rosari el meu avi era un costum que es veu que li venia d'un capellà, oncle seu, que l'havia educat, i diu que encara havia tingut un parell més d'oncles capellans que no l'havien educat. MB

SCRIPTA, Revista internacional de literatura i cultura medieval i moderna, núm. 17 / juny 2021 / pp. 581 - 615 
Josep Vicent Garcia Sebastià. La llengua en l'obra narrativa de Carmelina Sánchez-Cutillas: vers la construcció d'un model de referència al País Valencià

149) I nosaltres vivíem com sí visquéssem a cavall entre el poble i Capnegret; al poble la casa de l'avi i les dels oncles, i a Capnegret la casa dels pares vora la carretera però a aquesta banda, i només de creuar la carretera, la Venta del tio Catalí i mitja dotzena de bancals i de marges i en acabant la mar. MB 33

150) Però el rellotge de mon tio Miquel no s'assemblava a cap. MB 64

En gairebé tots els casos documentats, el substantiu tio designa persones d'estrat humil, encara que no siguen parents de qui els anomena. Aquesta tendència, exemplificada en 146) i 147), es correspon amb l'ús d'una fórmula de tractament distintiva del valencià col loquial (DCVB, s. v. tio, 4). La relació de parentiu, en canvi, s'expressa per mitjà de la paraula oncle-148)-, tal com és propi del català general. Per tant, l'aparició d'una forma o l'altra en el discurs narratiu no és arbitrària, sinó que respon a un criteri semanticopragmàtic ben definit. S'observa clarament en 149). L'única excepció la reproduïm en 150), en què tio equival a oncle, una irregularitat en la prosa de l'autora que podria justificar-se per la combinació d'aquest vocable amb el possessiu àton mon.

xicotet/petit $\mathrm{i}$ altres

151) Anava amb ella la filla petita de la comandanta(...). MB 38

152) De tant en tant una gota d'aigua, en pegar contra una pedra més grossa, ens esguitava i després s'anava escolant per sobre la nostra carn com un petit rierol. MB 57

153) A voltes un carranc xicotet (...) es quedava presoner de l'aigua-sal dels clotets empedrida i brillosa. LLSR $199^{28}$

154) Però només de donar-me el paquet començà a riure, i com que mon avi volia saber el motiu ell va dir «que no la veu?, $\tan$ xicoteta i acabe de deixar entre les seues mans tota la Matèria de Bretanya»

155) Uns i altres eren descendents dels xicotets Regnes de Taifes (...). LLSR 202

156) A l'estiu les xiquetes i els xiquets més menuts anaven en conill o amb una camiseta de tela que no els aplegava al melic. MB 35

L’adjectiu que fa servir Sánchez-Cutillas amb més freqüència per referir-se al contrari de 'gran -en sentit ampli-, nombrós o d'edat avançada' és petit/ $a$, el qual està ben documentat en la llengua dels clàssics i és propi del català general. Aquest mot alterna amb l'ús -molt més reduït- de xicotet/a, una solució valenciana d'extensió més restringida. Sovint, trobem aquesta forma en fragments de discurs reportat, com ara en 154), un fet que es podria relacionar amb la intenció per part de l'escriptora de reproduir el valencià oral. També és significativa la tendència de reservar petit per als usos anteposats al substantiu, tal com s'il lustra en 152). ${ }^{29}$ No debades, només trobem un

28 L'exemple 153) il lustra la integració de formes valencianes d'abast més restringit, xicotet, amb elements lèxics d'altres parlars del català -sobretot del dialecte central-, carranc.

29 Aquest tret es formalitza en un total de 9 exemples.

SCRIPTA, Revista internacional de literatura i cultura medieval i moderna, núm. 17 / juny 2021 / pp. 581 - 615 
exemple en què xicotet apareix en aquesta posició -el reproduïm en 155)-. A banda de les solucions esmentades, atestem en un sol cas la utilització de menut/da com a adjectiu, 156).

xiquet/nen $\mathrm{i}$ altres

157) Els homes i les dones i els xiquets del passat estan vius encara en la meua memòria, constitueixen el lligam entre el present i l'absència. MB 29

158) De tant en tant els xicons eixíem a la via al pas del tren, adéu adéu (...). MB 45

159) Tanmateix, no vaig voler parlar de la mestra Cantarrana, sempre aixoplugant nens en la seua costura com una mena de mare o com una mena de lloca. MB 72

160) I quan els grans soterraren la mare Paula, nosaltres, els nins, vam soterrar moltes coses. MB 58

161) I com que havia alletat un oncle meu, se l'afillà per a sempre, car al poble quan una dona cria un menut que no és el seu fill, se l'afilla perquè li ha donat la seua llet (...). MB 56

162) Però un dia va morir la mare Paula, i tota la menudalla l'acompanyàrem al cementeri. MB 58

163) Al poble també hi havia moltes costures de tenir cura dels xicotius, i el mateix anaven nens com nenes. MB 70

164) Jo també vaig anar-hi, molt intrigada pensant d'on haurien tret aquell monyicot que dormia al mig de tot el llit dels seus pares. MB 11

165) A l'endemà vaig fer la prova de passejar el criançó, però en comptes d'un xiquet semblava un farcell de roba de contraban (...). MB 119

La 'persona que es troba en els primers anys de la vida' es designa, majoritàriament, per mitjà dels vocables xiquet/a, xicon/a i nen/a i -cf. 157), 158) i 159). ${ }^{30}$ Les dues primeres formes són característiques dels parlars valencians. ${ }^{31}$ En canvi, nen/a és una solució que ocupa bona part del Principat (PALDC: mapa 359). Menys freqüents són les denominacions $\mathrm{nin} / \mathrm{a}-160)-$, pròpia del mallorquí i el rossellonès (PALDC: mapa 359)-, menut/da -161-, paraula bastant generalitzada arreu del domini lingüístic, el derivat menudalla-162)-, que té un sentit col lectiu, i xicotiu/a-163)-, d'un marcat caràcter afectiu (Garcia 2017: 77-78). A més, també documentem l'ús de significants més específics, com ara monyicot-164) - o criançó -165) - els quals fan referència a un 'infant que encara mama'.

30 Per bé que en valencià xicon sol designar una 'persona jove', no necessàriament un infant, en la narrativa de SánchezCutillas s'utilitza com a sinònim absolut de nen o xiquet, tal com suggereixen diversos exemples com el que hem reproduït en 158 ).

31 Segons les dades que ens forneix el PALDC (mapa 359), xiquet/ a és una forma amb molta més extensió que no pas xicon/ $a$, la qual només ocupa una zona del migjorn valencià. 
Josep Vicent Garcia Sebastià. La llengua en l'obra narrativa de Carmelina Sánchez-Cutillas: vers la construcció d'un model de referència al País Valencià

\subsection{Altres usos lèxics}

Més enllà de la variació sinonímica, la combinació d'elements lèxics de procedència diversa en el model de Carmelina Sánchez-Cutillas també s'observa en:

a) La preferència per mots habituals en valencià, ${ }^{32}$ que es consideren cultes perquè estan avalats pels usos literaris o bé perquè es corresponen amb la forma etimològica, com per exemple alçar ('aixecar', MB 33, 37), aplegar ('arribar'; MB, 34), afonar-se (MB 127), (MB 77), albarzer (MB 127), alfäbega (MB 61, 69), arruixar (MB 118), atifell (MB 38), bord ('que actua amb malícia', MB 41), cànter (MB 58), cartó (MB 110), cementeri (MB 50), colp (MB 34), dacsa (MB 35), ${ }^{33}$ desficaci (MB 128), desphis-ahir (MB 107), trellat ('raó, fonament lògic', MB 68, 71 , 94), enfit (MB 97), esgolar (MB 53, 119), granera (MB 77) i agranar (MB 71), melic (MB 68), menudalla ('xicalla', MB 63), murta (MB 63), panolla (MB 35), pebrera (MB 106), pitxer (MB 61, 76, 107), sesta (MB 120), soterrar (subst. 'enterrament', MB 50) o vesprada (MB 95).

b) La proliferació de solucions generals i prestigiades pels usos formals -i, en algun cas, difoses per la llengua literària contemporània- com ara amanir ('preparar', $\mathrm{MB}$ 119), ampolla (MB 38, 96), argent (MB 65), avi/ avvia (MB 49, entre altres), avui (MB 35, 36), bacallà (MB 60), calaix i calaixera (MB 38, 119), coïssor (MB 109), eina (MB 123), empentar (LLSR 202, MB 35), emprendre (MB 107), enteixinat (MB 83), escanyolir (MB 77), escuma (MB 96, LLSR 199), esquinçar (MB 93), estel ('cos celeste', MB 64), estrìnyer (MB 114), façana (MB 44), fibló (MB 109), graó i graonada (MB 61), joia ('alegria', MB 45), ocell (MB 82), oir (MB 71), papallona (MB 55), ${ }^{34}$ petjar (MB 65), regalimar (MB 93), replà (MB 129), romaní (MB 109), ros (MB 39), tafanejar (MB 67), trigar (MB 64), trucar ('donar colps a la porta per demanar que òbriguen', MB 100), vaixell (MB 38), vesc (MB 127), vuit (MB 44), xemeneia (MB 111) o xuclar (MB 66).

c) La inclusió de formes pròpies d'altres varietats de la llengua, sobretot del dialecte oriental. És el cas d'aixafar (MB 122), cordill (MB 63), cridòria (MB 50), esbaltir (MB 127), estripar (MB 100), faldilla (MB 75), farcell (MB 119), febre (MB 110), feina (LLSR 201), la locució amb prou feines (MB 72) i el derivat feiner/a (MB 109), gronxar-se $i$ gronxador (MB 37), heura (MB 127), llamí (MB 108), llaminadura (MB 100) i llaminer/a (MB 109), relliscós (MB 116), sorra (MB 39), tombarella (MB 88), trepitjar (MB 125), xerrameca (MB 78), ximple (MB 60) o xop ('completament moll', MB 70). A més, també testimoniem l'ús de l'adverbi horabaixa (MB 130), que actualment designa en baleàric l'hora crepuscular -tot i que està ben documentat en textos valencians del segle XV, com ara el Tirant (DCVB, s. v. horabaixa, 2).

32 El fet que siguen mots habituals en valencià no vol dir que, almenys alguns, no siguen també vius en altres territoris.

33 El vocable dacsa predomina en el valencià central i en bona part de les Marines. De fet, és la forma general a Altea per a denominar el 'blat de moro' (PALDC: mapa 521).

34 També papallona de la llum (MB 55), locució referida a les palometes que volten la llum de nit.

SCRIPTA, Revista internacional de literatura i cultura medieval i moderna, núm. 17 / juny 2021 / pp. 581 - 615 
d) La incorporació de vocables que remeten a la llengua antiga: ${ }^{35}$ cascú (MB 77) i cascun/a (MB 54, 62), coltellada (MB 127), ensems (MB 49), esguard (MB 103), la locució fora vila (MB 62), fosca ('foscor', MB 105), glassa ('gasa' MB 59), glavi (MB 84), hom (MB 35), mesnada ('mainada', MB 50), orb (MB 103) o remembrança (MB 105).

e) L'ús de solucions territorials d'extensió més reduïda: acubilar (variant del verb acovilar, 'refugiar en un cau o un amagatall', viu en els parlars meridionals -cf. DCVB acovilar, 1-; LLSR 200), la locució armar un cartapell ('armar un embolic', Martines 2012: 79-80; MB 128), camiseta (MB 35), desficaciament (LSG 201), desllapissar ('separar una cosa que està agafada amb una altra o que hi està vinculada per alguna mena de lligam', MB, 128), eixancamallar ('eixancar', Martines 2012: 100; «(...) ben eixancamallats en el seu cavall (...)», MB 128), escaldó [de la pansa] ('escaldada', MB 123), mançaneta ('botó', MB 42, 48), monesillo ('escolanet', MB 50, 59, 57), ${ }^{36}$ mormolar ('renyar, bonegar', MB 67), paixarell (MB 126), pedra codissa ('pedra de riera', MB 43), plàtera ('plata', MB 59, LLSR 202), teuladí ('ocell de l'espècie Passer domesticus, pardal', MB 90, 118) o vedriola (MB 100, 101). A banda d'aquestes formes de caràcter restringit, l'autora literaturitza localismes d'Altea o dialectalismes de la Marina Baixa. Considerem que el fet d'oferir una petita mostra d'aquests usos pot resultar interessant: ${ }^{37}$

i. alcoletja 'terra d'horta guanyada al riu': «(...) quan arribava l'estiu (...) i se n'anaven (...) a l'alcoletja del riu (...)» (MB 43); «I les alcoletges eren uns bancals amb el seu parral i la figuera de figues de cameta $\mathrm{i}$ tot (...)» (MB 43); «Hi havia alcoletges a muntó, perquè la terra guanyada al senyoriu de l'Algar (...) no la cobraven (...)» (MB 43). Colomina (1991: 90-91), que en documenta la variant algoletja, situa el mot a Callosa, Altea i Polop.

ii. casup. Forma que testimoniem en diminutiu, casupet, designa una 'caseta menuda i pobra'. En Matèria de Bretanya fa referència de manera més específica a les barraques que es construien a la vora del riu, segurament per a emmagatzemar-hi les eines o, fins i tot, per a guarir-se o passar-hi alguns dies: «(...)

35 Tot i que ha passat desapercebuda, una faceta important de Carmelina Sánchez-Cutillas és la seua tasca com a investigadora de la història i la literatura catalanes antigues (Francés 2020); per tant, l'autora devia estar ben familiaritzada amb la llengua dels clàssics. Recordem també que va escriure una narració en què es feia passar per sor Isabel de Villena i en què recreà el català antic, «A la reverent e honrada Sor Francina de Bellpuig, monja professa al convent de la Puritat cara cosina nostra» (1981).

36 Hem pogut comprovar que en la versió mecanoscrita de Matèria de Bretanya que es conserva a la Biblioteca Valenciana Nicolau Primitiu l'autora optà en un primer moment per la forma escolà. Amb tot, la substituí posteriorment i en tots els casos per monesillo, tal com demostren les correccions del text.

37 La majoria d'aquests vocables s'han documentat també en l’obra de Francesc Martínez i Martínez (Colomina 1991), avi de Carmelina Sánchez-Cutillas, pel qual l'escriptora sentia una profunda estima i admiració. No seria desenraonat suposar que els escrits i els usos lingüístics de Martínez i Martínez degueren exercir una influència notable en el model de Sánchez-Cutillas. Almenys així ho suggereix alguna de les referències de l'autora a la llengua del seu avi i al valencià de la Marina: «(...) [Francesc Martínez i Martínez] ingresó en la Sociedad «Lo Rat Penat», con lo que comenzó su entrega total a la causa de la lengua valenciana, que él hablaba en su forma más pura y más bella -tal como se ha conservado en toda la Marina- (...)» (Sánchez-Cutillas 1974: 32-33).

SCRIPTA, Revista internacional de literatura i cultura medieval i moderna, núm. 17 / juny 2021 / pp. 581 - 615 ISSN: 2340-4841 $\cdot$ doi:10.7203/SCRIPTA.17.20925 
sembraven el bancal i enllestien la caseta amb canyissos i floques de xiprer i era com una barraca un casupet> $(\mathrm{MB}, 43)$.

iii. maruà. Vocable que a la localitat d'Altea denomina 'l'estorí redó de llata per a posar-hi els peus', segons el DCVB (s. v. maruà, 2): «(...) nosaltres ens ficàvem sobre el maruà, que era una estora rodona feta d'espart» (MB 57). Però hi ha un cas en què maruà té més a veure amb el 'ventador d'espart per al foc', sentit documentat en l'obra de Francesc Martínez i Martínez (Colomina 1991: 236; Martines 2000: 169): «Per això, si tanque els ulls, m’oblide de tot el temps ventat pel maruanet dels anys» (MB, 101). Aquest altre ús deu estar més estès, ja que Colomina (1991: el localitza a Benidorm -amb la forma maurà, generada per metàtesi- i el DCVB (s. v. marguà) a Eivissa.

iv. micona. Variant intensiva de mica que encara perviu a la comarca (Colomina 1991: 241): «Jo passava llargues temporades amb ma tia (...) i m'agradava d'anar-hi i aprenia d'ella coses estranyes que em corprenien i ensems em donaven una micona de por (...)» (MB 77).

petgelina 'petxina'. En Matèria de Bretanya, eufemisme referit al sexe femení: «(...) els xiquets pixen per un peixet i les xiquetes per una petgelina» (MB 119). Colomina (1991: 267) atribueix l'ús de la grafia tg a una ultracorrecció de petxelina que hauria estat introduïda per la mà del revisor. Però el fet cert és que en el mecanoscrit de l'obra, dipositat a la caixa 20 del llegat de Carmelina Sánchez-Cutillas a la Biblioteca Valenciana Nicolau Primitiu, ja documentem la variant gràfica petgelina. Siga com siga, petxelina s'estén, entre altres zones (DCVB, s. v. petxelina), per diverses localitats de la Marina Baixa, entre les quals hi ha Altea.

vi. sàssia. Variant d'eixàrcia, 'arreu de pesca format per una teixit de fils nugats que formen una retícula quadrada o romboidal': «Aquesta costera feia olor de peix i de saladura i per davant de les portes penjaven cortines de sàssia negra; i açò volia dir que encara érem al barri dels mariners» (MB 35). La paraula antiga eixàrcia, que també podia usar-se amb el mateix significat, s’ha conservat amb diferents formes en el català actual. La que es fa servir a algunes localitats de la Marina Baixa -entre les quals hi ha Altea- és sàssia, resultat d'una despalatalització i d'una reducció de rs a ss (Colomina 1999: 346).

vii. saullà. Variant dialectal -i gràfica- de segullada, 'foixarda, mata de la família de les globulariàcies, de l'espècie Gobularia alypum': «(...) amb el poliol i la saullà farien tassetes d'herbes (...)» (MB 127). En català hi ha un gran nombre de denominacions populars per a designar aquesta planta -el CERCATERM n'arreplega més de vuitanta (s. v. foixarda). Concretament, el vocable segullada i les diverses variants (segollada, sagullada, saüllà, etc.) podrien provenir de cebollada segons el DECat (s. v. ceba i sebollada). En qualsevol cas, Sánchez-Cutillas opta per designar la Globularia alypum amb la forma més acostada al parlar d'Altea: segullada, pronunciada [sauḱá] (Colomina 1999: 295). 
Josep Vicent Garcia Sebastià. La llengua en l'obra narrativa de Carmelina Sánchez-Cutillas: vers la construcció d'un model de referència al País Valencià

viii. tovallol. 'tovalló gran' a Altea (DCVB, s. v. tovallol, 1): «I les mones (...) ben embolicades dins un tovallol ratllat amb ratlles roges i grogues. I aquell tovallol era de llana (...)» (MB, 62). El DCVB en dona un exemple de Francesc Martínez i Martínez: «El pa... embolicat en un tovallol... es deposita en una cistella, Martínez Folkl. I, 34» (s. v. tovallol, 1).

f) L'agregació puntual de castellanismes. Algunes interferències són històriques o de caràcter dialectal: aguardar ('esperar', forma que el DCVB localitza al Maestrat, a Mallorca i a Menorca, s. v. aguardar, 3; encara que actualment també és viva a les Valls del Vinalopó i al Baix Vinalopó i, fins i tot, es conserva fossilitzada en frases fetes a la Canyada, l'Alcoià, ${ }^{38}$ LLSR 201), apretar (documentat pel DCVB en el segle XVII, s. v. apretar, 2; MB 35, 77), armilla (del castellà almilla, s'ha difós sobretot en el català central, DCVB s. v. armilla, 2; MB 86, 125), batidor ('pinta', castellanisme estès per algunes àrees del valencià i viu en el parlar d'Altea; MB 70), bonico (per bonic, el DCVB el documenta en l'Espill de Jaume Roig; MB 50); burro ('ase'; segons el DCVB, aquest ús ha arrelat modernament al País Valencià i a Catalunya, mentre que a Mallorca i a Menorca s’usa únicament amb un sentit despectiu per a designar persones curtes d'enteniment; MB 53) i nòvio [sic] (variant de nóvio, barbarisme generalitzat arreu del domini; el DCVB en documenta exemples del segle XV; MB 71). Altres castellanismes són més actuals i apareixen marcats en cursiva; en tots aquests casos, la veu narrativa reprodueix la manera de denominar una determinada realitat en la parla col loquial de l'època: adiós (LLSR 198), estrado (MB 130), fascista (LLSR 203), jefe (MB 44), lorito (referit a la repetició que implica per al creient resar el rosari, MB 40) i puesto ('lloc, posició', LLSR 199). L'únic barbarisme que ni és històric ni dialectal ni té cap marca tipogràfica és l'adjectiu milagrós: «(...) acordaven de treure en processó les imatges més milagroses de l’església» (MB 91).

Un altre tret destacable del model lingüístic de Sánchez-Cutillas és la utilització del lèxic per a evocar uns cronotops i unes formes de vida en desaparició (Mira 2017: 52): els dels ambients populars d'Altea abans i durant bona part de la guerra civil. En un altre estudi ja apuntàvem que entre els elements que l'autora -o la veu narrativa- intenta salvar de l'oblit també hi ha la llengua de començaments del segle XX (Garcia 2017: 87). A tall d'exemple, i sense cap pretensió d'exhaustivitat, enumerarem ara un seguit d'unitats lèxiques d'índole diversa que il lustren aquesta estratègia. Les hem classificades en sis blocs:

a) Lèxic agrícola: aixada (MB 127), anganelles (LLSR 203), corbella (MB 127), cornial (MB 35), emparrat (LLSR 199), espigó (MB 69), falcó (MB 127), mestall (LLSR 204), morca (MB 96), ordi (LLSR 204), regueró [d'aigua] (MB 43), riu-rau (MB 122), ronsal (MB 110), saranda (MB 57), sària (MB 35, 109), segó (LLSR 204), sègol (LLSR 204), sequer (MB 62), vinya (MB 90).

b) Lèxic de la gastronomia tradicional: arrop i talladetes (MB 110), arròs fadrí (LLSR 204), bamba ('ensaïmada', LLSR 203), bollos a la paleta (MB 96), ${ }^{39}$ bullit (MB 40), herbero (MB 127), pablanc (LLSR 203), prendre col lació (MB

38 Agraim al professor Vicent Beltran que ens haja facilitat aquesta informació.

39 El castellanisme bollo s'empra a la Marina per designar una coca farcida de verdura i de peix típica de la zona. La

SCRIPTA, Revista internacional de literatura i cultura medieval i moderna, núm. 17 / juny 2021 / pp. 581 - 615 ISSN: 2340-4841 · doi:10.7203/SCRIPTA.17.20925 
Josep Vicent Garcia Sebastià. La llengua en l'obra narrativa de Carmelina Sánchez-Cutillas: vers la construcció d'un model de referència al País Valencià

60), putxero (MB 76), regalèssia (MB 114), reganyat ('peça de pa llarguera amb regruixos o ramificacions curtes a cada costat', DCVB, s. v. reganyat, 3; LLSR 204), xambit (MB 92).

c) Noms de jocs populars: burro ('joc de cartes', MB 120), calig (variant de calitx, 'joc que es fa posant un canut o una pedra dreta en terra, damunt el qual es col loquen monedes petites; els jugadors tiren amb una altra moneda al calitx, i s'apodera de les monedes aquell que les tomba', DCVB, s. v. calitx; MB 106), cèrcol (alterna amb el sinònim rotgle: «(...) aquell nen va traure no sé d'on un cèrcol o rotgle de ferro, i el feia rodar empentant-lo amb un filferro», MB 51), fer arca (MB 106), jugar a clotets ('joc infantil que consisteix a fer un clot petit en terra i tirar monedes o altres peces de joc procurant que vagen a parar dins el clot', DCVB, s. v. clotet, 1; MB 71), xamelo ('joc de dòmino', MB 117).

d) Noms de criatures imaginàries i altres creences: focs follets (MB 68), gambosi (MB 83), näixer amb camiseta (MB 75), por ('fantasma', MB 47).

a) Noms d'ocells: gafarró (MB 126, LLSR 198), merla (LLSR 198), paixarell (MB 126), teuladí (MB 90, 118), verderol (MB 126),

b) Fitònims: alfábega (MB 69), ametller (MB 35), argelac (MB 111) i argelaga (MB 112), baladre (MB 66), besneula (MB 66), camamirla (MB 111) i camamilla (MB 112), canyar (LLSR 199, 201), cascall (MB 96), clavellina (MB 69), esparreguera (MB 107), farigola (MB 94), friula (MB 127) i timó (MB 127), figuera (MB 43, LLSR 200), garrofer (MB 91), greda (MB 94), heura (MB 94), matafaluga (MB 127), murta (MB 65), olivera (MB 91), parra (LLSR 199), poliol (MB 127), rosella (MB 102), ruda (MB 66), salze (MB 29), saullà (MB 127), taronger (LLSR 203). ${ }^{40}$

La voluntat per reviure el valencià popular d'Altea també s'observa en determinades reflexions metalingüístiques (Borja 2010: 99) que testimonien fenòmens de variació i canvi lingüístics. La més coneguda és la que versa sobre el significat dels adjectius guapo ('robust, de bon aspecte, ben criat') i polit ('bell i bonic', però també 'gran i gros, robust'), que en determinats contextos es poden arribar a usar com a sinònims:

166) Les dones de les costeres li deien a ma mare que que polida estava jo, i a mi no m'agradava gens car em semblava que polida volia dir grandota, $i$ apretava a córrer empentada per la ràbia i pensant que tota aqueixa gent era una destrellatada, perquè a les xicones ens deien polides però en veure una bacona de cria amb bones mamelles començaven a dir que quina bacona més guapa, i si es topaven amb un matxo jove amb la sària plena de càrrega deien que era un matxo molt guapo, i els ametllers eren guapos $\mathrm{i}$ les panolles de dacsa eren guapes $\mathrm{i}$ tot tot, menys les xicones. (MB 35)

veu narrativa de Matèria de Bretanya ens en dona la recepta: «I aquells bollos eren una mena de coques de farina de dacsa escaldada, i se'ls afegia un raig de l'oli del setrill i es farcien amb bledes o amb espinacs i molletes de peix blanquet o de melva» (MB 96).

40 Sobre el significat dels elements vegetals en Matèria de Bretanya, cf. Pons (2017).

SCRIPTA, Revista internacional de literatura i cultura medieval i moderna, núm. 17 / juny 2021 / pp. 581 - 615 
Però n’hi ha més. Així, l'ús de tio/ tia que hem exposat en $\int 4$ 4.1. (cf. supra) també l'explica de manera explícita la veu narrativa de Matèria de Bretanya. En aquest cas, la narradora especifica quin és el criteri per a utilitzar la fórmula de tractament tia referida a les dones: havien de ser d'edat avançada o bé ser joves i estar casades. Ho exemplifiquem en 167).

167) La tia Agnamaria era tia meua de debò -i si ho dic així és perquè, al poble, a totes les dones se’ls deia ties, a les velles malgrat que fossen fadrines i a les casades malgrat que fossen joves-. (MB 76)

Finalment, en algun d'aquests usos s'explica, per mitjà de la forma més general en català, el significat d'un eufemisme -168)-, d'una denominació popular -169)-, d'un dialectalisme -170)- o d'un sinònim -171):

168) (...) i de vegades jo em descordava les dos mançanetes de més amunt del meu vestit perquè ell mateix [el crucifix] s'amagàs. I al poble deien mançanes per no dir botons, ja que botons volia dir altra cosa prou indecent. (MB 42)

169) I hi havia parotets i marotetes, que la gent sabuda diu libèl lules. I nosaltres aleshores sabíem quin era el parotet i quina la maroteta, però ara ja he oblidat com ho sabíem (MB 58)

170) Ella es semblava als melons i a les carabasses, només que el seu cap era tot ple d'ones d'aqueixes que es feien, a colps de batidor i amb els cabells ben xops. I per a pentinar-la anava tots els matins una pentinadora. Però m’oblidava de dir que la gent del poble a la pinta li diu batidor, i les pintes són les pintes d'aguantar-se el pentinat. (MB 70)

171) (...) perquè allí les gallines i els bacons -que vol dir els porcs-i els pollastres anaven solts pels carrers tot el dia (...). (MB 87)

\section{Conclusions}

En general, coincidim amb Borja quan afirma que «Carmelina crea, quant al model lingüístic, una de les més sòlides propostes en les bases de la normalització que més tardanament es produirà en el conreu del gènere novel lístic al País Valencià» (Borja 2010: 102-103). Més enllà de les vacil lacions i els dubtes, generalitzats en la creació literària de l'època (Carbó \& Simbor 1993: 28-38), l'escriptora reeixí a integrar en un únic model (a) solucions del model congriat a l'entorn de l'obra de Fabra importades dels usos literaris que s'havien començat a consolidar al Principat, (b) variants valencianes prestigiades pels usos cultes de la llengua i (c) formes del parlar de la comarca de la Marina Baixa i localismes d'Altea, amb els quals l'autora enriquí el lèxic comú. Aquesta és una estratègia molt semblant a la que també feia servir Enric Valor en la seua obra narrativa (Martines Llinares en premsa).

La llengua de Sánchez-Cutillas bascula entre l'aparença infantil, popular i col loquial (Salvador 2013: 163-165; Garcia 2017) i la formalitat pròpia dels usos literaris més cultes. A més, també té el mèrit d'elevar a la categoria literària solucions dialectals, del parlar d'Altea i de la Marina, sense 
Josep Vicent Garcia Sebastià. La llengua en l'obra narrativa de Carmelina Sánchez-Cutillas: vers la construcció d'un model de referència al País Valencià

renunciar en cap cas a la màxima convergència amb la resta de varietats del català. El model lingüístic de l'autora entronca, doncs, amb el de la majoria de lletraferits valencians del moment, inspirats pel mateix ideal idiomàtic que el de Sanchis Guarner o el d'Enric Valor: la construcció, després d'una llarga travessia pel desert editorial valencià, d'un català literari policèntric però convergent (Ferrando 2019: 308-310; 334-375). 
Josep Vicent Garcia Sebastià. La llengua en l'obra narrativa de Carmelina Sánchez-Cutillas: vers la construcció d'un model de referència al País Valencià

\section{Bibliografia}

ALDC = Veny, J./Pons, L. (2001- ) Atles lingüistic del domini català, Barcelona, Institut d'Estudis Catalans.

Alpera, Ll. (1997) «Introducció», dins Sánchez-Cutillas, C., Obra poètica, València, Generalitat Valenciana, pp. 9-36.

Antolí, J. (2015) L'evidencialitat en català antic: estudi de corpus i acostament segons la gramàtica cognitiva [tesi doctoral], Alacant, Universitat d'Alacant.

Balaguer, E. (1993) «Els seixanta. El furor d'una dècada (Balanç de la poesia valenciana)», L'Aiguadols, 18, pp. 9-22.

Beltran, V. (2010) «El parlar d'Altea i el registre literari de Carmelina Sánchez-Cutillas», ponència presentada en el curs «Carmelina Sánchez-Cutillas: matèria de memòria», Altea, 23/04/201008/05/2010.

Beltran, V./Segura, C. (2019 [1a ed. 2017]) Els parlars valencians, València, Publicacions de la Universitat de València.

Borja, J. (2010) «Carmelina Sánchez-Cutillas: matèria de memòria», Sarrià. Revista d’investigació i assaig de la Marina Baixa, 4, pp. 96-105.

Broch, À. (1980) La literatura catalana dels anys 70, Barcelona, Edicions 62.

Carbó, F./Simbor, V. (1993) La recuperació literària en la postguerra valenciana (1939-1972), València/ Barcelona, Publicacions de l'Abadia de Montserrat.

Casanova, E. (2009) «El valencià, de llengua de carrer a llengua literària», dins Casanova, E./Garcia Frasquet, G. (eds.), Els escriptors valencians i la llengua literària, Gandia, CEIC Alfons el Vell, pp. $13-24$.

Casanova, E./Garcia Frasquet, G. (eds.) (2009) Els escriptors valencians i la llengua literària, Gandia, CEIC Alfons el Vell, pp. 13-24.

Casasses, E. (2009) «Porpra i caretes per als germans», El País, 26-02-2009.

Colomina, J. (1991) El valencià de la Marina Baixa, València, Generalitat Valenciana. - (2010) «El model de llengua literària en Carmelina Sánchez-Cutillas, ponència presentada en el curs «Carmelina Sánchez-Cutillas: matèria de memòria», Altea, 23/04/2010-08/05/2010.

DCVB = Alcover, A. M./Moll, F. B. (1985) Diccionari català-valencià-balear, Palma de Mallorca, Moll.

DDLC = Rafel, J. Dir. (1985-) Diccionari descriptiu de la llengua catalana, Barcelona, Institut d'Estudis Catalans.

DECat = Coromines, J. (1995) Diccionari etimologic i complementari de la llengua catalana, Barcelona, Curial Edicions Catalanes/La Caixa. 
Josep Vicent Garcia Sebastià. La llengua en l'obra narrativa de Carmelina Sánchez-Cutillas: vers la construcció d'un model de referència al País Valencià

Esteve, A. (2013) «Matèria de Bretanya, de Carmelina Sánchez-Cutillas, en el context de la literatura autobiogràfica contemporània», Caplletra, 55, pp. 153-174.

Ferrando, A. (2019 [1a ed. 2018]) Fabra Moll i Sanchis Guarner. La construcció d'una llengua moderna de cultura des de la diversitat, València, Publicacions de la Universitat de València.

Francés, M. À. (2020) «Carmelina Sánchez-Cutillas, Historiadora de la València medieval», Plecs d'Història Local, 178, 24.

Fuster, J. (1972) «Una carència singulan», Serra d’Or, 149, p. 31.

Garcia Sebastià, J. V. (2017) «L'oralitat en Matèria de Bretanya, de Carmelina Sánchez-Cutillas», L'Aiguadols, 46, pp. 73-90.

GIEC = Institut d'Estudis Catalans (2016) Gramàtica de la llengua catalana, Barcelona, Institut d'Estudis Catalans.

Institut d'Estudis Catalans (2017) Ortografia catalana, Barcelona, Institut d'Estudis Catalans.

Martines Llinares, J. D. (en premsa) «Caracterització del model lèxic i fraseològic d'Enric Valor: identificació i estandardització», dins Martines, J. (ed.), Norma, variació i identitat: el cas de la llengua catalana, Leipzig, Leipziger Universitätsverlag.

Martines Peres, J. (2002) El valencià del segle XIX. Estudi lingüístic del Diccionario valenciano de Josep Pla i Costa, Alacant/Barcelona, Institut Interuniversitari de Filologia Valenciana/Publicacions de l'Abadia de Montserrat.

—. (2012) El valencià del segle XIX: el lèxic, Barcelona, Institut d'Estudis Catalans.

Mira, I. (2017), «"Un feix de coses petites”: els espais de la quotidianitat en Carmelina SánchezCutillas i Vicent Andrés Estellés», L'Aiguadolç, 46, pp. 41-54.

Pérez Saldanya, M. \& Rigau, G. (2011) «Totz hic viuen ací, e yo sol no yc puc viure!: una aproximació històrica als adverbis demostratius», dins Lloret, M.-R./Pons, C. (eds.), Noves aproximacions a la fonologia $i$ la morfologia del català. Volum d'homenatge a Max W. Wheeler, Alacant, Institut Interuniversitari de Filologia Valenciana, pp. 459-488.

PALDC = Veny, J. (2007-2019) Petit Atles Lingüistic del Domini Català, Barcelona, Institut d'Estudis Catalans.

Piera, J. (2009) «Un flash dels anys 70», El País, 05-03-2009.

Pons, J. (2017) «Els elements del món vegetal en Matèria de Bretanya», L'Aiguadolc, pp. 91-99.

Salvador, V. (2013) «Mite i escriptura en Matèria de Bretanya de Carmelina Sánchez-Cutillas», dins Salvador, V. (ed.), Figures i esbossos. Estudis sobre literatura valenciana contemporània, Alacant, Institut Alacantí de Cultura Juan Gil-Albert, pp. 159-166. 
Josep Vicent Garcia Sebastià. La llengua en l'obra narrativa de Carmelina Sánchez-Cutillas: vers la construcció d'un model de referència al País Valencià

Sánchez-Cutillas, C. (1974) Francisco Martínezy Martinez: Un bumanista alteano (1866-1946), Alacant, Caixa d'Estalvis Provincial d'Alacant.

—_. (1979) «El llamp i la sageta de records», L’Espill, 1/2, pp. 179-205.

—. (1997) Obra poètica, València, Generalitat Valenciana.

—_. (2015 [1a ed. 1976]), Matèria de Bretanya, València, 3 i4.

Valor, E. (1999a [1a ed. 1977]), Curs mitjà de gramàtica catalana referida especialment al País Valencià, València, $3 i 4$.

—. (1999b [1a ed. 1979]), Millorem el llenguatge, València, 3i4.

SCRIPTA, Revista internacional de literatura i cultura medieval i moderna, núm. 17 / juny 2021 / pp. 581 - 615 ISSN: 2340-4841 · doi:10.7203/SCRIPTA.17.20925 